\title{
Executives' Legal Records and the Deterrent Effect of Corporate Governance
}

\author{
Robert H. Davidson* \\ Virginia Polytechnic Institute and State University \\ rhdx@vt.edu
}

\author{
Aiyesha Dey \\ Harvard Business School \\ Harvard University \\ adey@hbs.edu
}

\author{
Abbie Smith \\ The University of Chicago Booth School of Business \\ abbie.smith@chicagobooth.edu
}

\begin{abstract}
*Corresponding author: Robert H. Davidson, Virginia Polytechnic Institute and State University, Pamplin Hall, Suite 3098, 880 West Campus Drive Blacksburg, VA 24061; Phone: 773-263-3076; email: rhdx@vt.edu.

We are extremely grateful to the editor, Fabrizio Ferri, for numerous constructive comments and suggestions which improved the quality and substance of the paper significantly. We also thank two anonymous reviewers for their helpful suggestions. We acknowledge helpful comments from John Core, Christian Leuz, Rodrigo Verdi, Joshua White, Christine Zulehner, the workshop participants at University of Colorado, Duke University, Georgetown University, Indiana University, McGill University, MIT, and conference participants at the 2014 HBS Information, Markets, and Organizations Conference, 2013 Kellogg Accounting Research Conference, 2013 Virginia Accounting Research Conference, and the 2013 SAFE Conference on Transparency at Goethe University Frankfurt. We are grateful to Ryan Ball for providing a sample of bankrupt firms. We also appreciate the financial support of the Accounting Research Center, the Fama Miller Center, the IGM at the University of Chicago Booth School of Business, the James Ely III Fund for Research in Corporate Governance and the Center for Financial Markets and Policy at Georgetown University. All data used in this study are available from public sources and the sources are listed in the Appendix.
\end{abstract}




\title{
Executives’ Legal Records and the Deterrent Effect of Corporate Governance
}

\begin{abstract}
We study whether the effectiveness of corporate governance mechanisms varies depending on the characteristics of the executives subject to these mechanisms - namely, their "psychological type", as proxied by their history of legal infractions. In particular, we examine insider trading, where we can compare the trading behavior of different types of executives in the same firm. We find that "recordholder" executives, i.e., those with prior legal infractions, earn significantly higher profits from purchases and sales than nonrecordholder executives. Further, the profitability of both purchases and sales is significantly increasing in the severity of the infraction. Governance mechanisms, such as blackout policies, lower profits of executives with only traffic infractions; however, profits for executives with serious infractions appear insensitive to blackout policies. Insiders with serious infractions are also more likely to trade during blackout periods and before large information events and are more likely to report their trades to the SEC after the filing deadline. Collectively, our evidence suggests that while governance mechanisms can discipline executives with minor offenses, they appear largely ineffective for those with more serious infractions.
\end{abstract}

Keywords: Legal infractions; insider trading; corporate governance; blackout policy.

JEL Classification Codes: G30; G34; G38; G40; G41 


\section{Introduction}

A large literature examines the deterrent effect of corporate governance mechanisms on undesirable executive behavior. In this literature executives are largely treated as homogenous, effectively assuming that they all respond to these mechanisms in the same way. We relax this assumption and investigate whether and how the deterrent effect of corporate governance mechanisms varies across executives within the same firm based on individual characteristics.

To analyze executives' behavior, we focus on insider trading because it occurs at the individual level, not the firm level, and can be simultaneously observed for multiple executives within the same firm. This enables us to identify the effect of the same governance mechanism across different executives within the same firm. ${ }^{1}$ Further, insider trading continues to be an enforcement priority for regulators (Reuters Business News 2016).

As for executives' characteristics, our construct of interest is the executive's "psychological type” which we measure using legal records related to their off-the-job behavior. We interpret legal infractions, including traffic violations, driving under the influence of alcohol, drug-related charges, domestic violence, reckless behavior, and sexual assault, as a symptom of a relatively high disregard for rules/laws and lack of self-control. Further, we expect that more "serious" infractions (those beyond minor traffic infractions) reflect a higher degree of disregard for rules/laws and lack of self-control.

Finally, with respect to governance mechanisms, we focus on corporate blackout policies because they directly target insider trading. In brief, we predict that blackout policies are unlikely

\footnotetext{
${ }^{1}$ We use the terms "executives", "corporate insiders", or "insiders" to refer to those officers in a firm who are required to file trading reports under Section 16(a) of the Securities and Exchange Act of 1934 (often referred to as "Section 16 insiders"). Although Section 10(b) of the Securities and Exchange Act of 1934 and rule 10b-5 outlaws trades based on material, nonpublic information, we use the term "inside information" to refer to private information about a corporation that is available to insiders, regardless of whether that information is considered legally "material” under securities laws. Therefore, the insider trades analyzed are not necessarily illegal.
} 
to have a deterrent effect on informed trading for recordholder executives, particularly those with serious infractions.

Using a sample of 281 firms and 1,474 executives over 1986-2017, we first document that the profitability of both purchases and sales by recordholder executives is significantly higher than for other executives at the same firm and over the same time period. This result is more pronounced for recordholders with serious infractions, but also holds for recordholders with only traffic infractions. Next, we move to our primary analysis and examine how the deterrent effect of corporate governance varies with executives' legal records. We find that the profitability of purchases by recordholders is lower in firms with blackout policies, but only for recordholders with traffic infractions. In contrast, there is no evidence that profits from purchases by recordholders with serious infractions are related to the existence of blackout policies. Turning to insider sales, the profitability of sales by recordholders is not significantly associated with the existence of blackout policies. These results are robust to controlling for Rule 10b5-1 trades.

Collectively, our results suggest that executives' "psychological type” (as proxied by their legal infractions) affects their response to monitoring mechanisms. Especially concerning, executives with serious infractions appear insensitive to mechanisms governing insider trading.

Our analysis thus far does not directly establish that recordholders' trades constitute undesirable behavior. Two additional tests address this question. First, recordholders with serious infractions are 14 percent more likely to trade during blackout periods (and thus violate blackout policies) as compared to other executives at the same firm. Second, recordholder executives are more likely to fail to meet SEC timely reporting requirements (filing of Form 4 with the SEC). ${ }^{2}$ Prior to August 29, 2002, corporate insiders were required to report their trades before the 10th

\footnotetext{
${ }^{2}$ The SEC emphasizes the importance of these filing deadlines, and has been known to file charges against late filers (Harvison 2018).
} 
day of the following calendar month. From August 29, 2002 onwards they are required to report within 2 trading days after the trade. As compared to nonrecordholder executives, serious recordholders are more likely to report their trades late both before and after August 29, 2002. Further, conditional on being late, they file about seven days later on average than other insiders.

While violating blackout policies and filing forms late are evidence of undesirable trading, these findings do not address whether the trades themselves are more likely to be illegal. We cannot directly identify illegal trading, ${ }^{3}$ but perform two tests suggesting that insider trades by recordholder executives are more likely to be based on material, non-public information. For example, recordholder executives are 11 percent more likely to trade in the 60 days prior to large price-moving information events (such as mergers and acquisitions, earnings announcements, and stock and debt offerings) compared to nonrecordholder executives. And in particular, insider net sales prior to bankruptcy are largely driven by recordholder CEOs. Further, the recordholder classification has incremental power in predicting future portfolio returns.

Our primary contribution is to the corporate governance literature. While many studies conclude that the effectiveness of governance mechanisms depends on firm-level characteristics and that "one size does not fit all” (e.g., Coles et al. 2008; Dey 2008), ours is the first study to posit that, within the same firm, the effectiveness of those mechanisms varies across executives based on personal characteristics (as proxied by the presence and severity of legal infractions). While strong governance appears to significantly restrain executives with only minor (traffic) offenses, it appears largely ineffective for executives with more serious offenses. This evidence creates a challenge for boards and regulators who wish to discourage opportunistic insider

\footnotetext{
${ }^{3}$ We use data on insider trading from publicly available reports filed with the SEC as required by Section 16(a) of the Securities and Exchange Act of 1934. As Bainbridge (2000) notes, it is not clear whether executives will report their violations of Rule $10 \mathrm{~b} 5$ which prohibits insider trading based on material, nonpublic information, suggesting that we may not capture the most egregious cases of insider trading. If this is true then it is possible that our results represent a lower bound and the effects we document are more pronounced for the most egregious insider trading cases.
} 
trading and, more generally, limit other undesirable behavior, and speaks to the limits of formal control systems in deterring certain behavior. One potential implication of our results is that formal systems (such as structural governance and regulations) could be complemented with informal systems, such as strong corporate cultures, belief systems, peer reviews etc., to create a stronger system of controls in an organization (e.g., Guiso et al. 2015; Bereskin et al. 2014).

Our study also contributes to the literature on insider trading in three ways. First, we document that senior executives’ propensity to take advantage of informed trading opportunities varies in an intuitive way with their "psychological type”, identified on the basis of their off-thejob legal infractions. Our evidence complements the evidence in Kallunki et al. (2016) who find similar results using tax noncompliance in Sweden, and adds to the emerging body of research that seeks to identify executives' attributes that drive insider trading (e.g., Bhattacharya and Marshall 2012; Hillier et al. 2015). Further, in addition to the presence/absence of legal infractions, we provide novel evidence on how the severity of legal infractions is related to executives’ trading behavior. Second, and relatedly, while prior studies document the average deterrent effect of certain corporate governance mechanisms on insider trading (e.g., Ravina and Sapienza 2010; Jagolinzer et al. 2011), we explore how their effectiveness varies across executives in the same firm. Third, the bulk of the literature has documented abnormal returns following purchases but failed to do so for sales. In contrast, we find that the profitability of both purchases and sales by recordholder executives is significantly higher than for other senior executives at the same firm.

Finally, our study adds to the growing literature on CEO personal characteristics and style. While most studies look at the effect of these characteristics on corporate outcomes (e.g., Ham et al. 2017; Schoar and Zuo 2017), we examine their impact on individual actions. 


\section{Theoretical framework}

In section 2.1 we discuss the literature and our predictions related to executive type and insider trading and in section 2.2 we discuss our predictions related to the deterrent effect of corporate governance across executives.

\subsection{Executive type and insider trading profitability}

A large body of research suggests that senior officers and directors trade on more valuable information than those outside the firm (e.g., Lin and Howe 1990; Ke et al. 2003; Huddart et al. 2007). In general, the literature documents that while insider purchases earn significant abnormal returns, insider sales do not (Lakonishok and Lee 2001), presumably because many insider sales are for liquidity/diversification purposes and/or have greater exposure to litigation risk (Cheng and Lo 2006). While most of this research treats executives as homogeneous with respect to their propensity to trade on inside information, a few studies examine how various executive-specific factors are related to insider trading.

Hillier et al. (2015) find that executives' personal attributes (as proxied by fixed effects) explain up to a third of the variation in insider trading performance and dominate unobservable and observable firm and trade characteristics. ${ }^{4}$ Bhattacharya and Marshall (2012) document that managers who were indicted for illegal insider trading between 1989 and 2002 were richer and better paid. They speculate that psychological factors (rather than financial motives) contribute to insider trading. Kallunki et al. (2018) examine this possibility using Swedish executives and find that informed insider selling is more likely among less wealthy executives, and, conditional

\footnotetext{
${ }^{4}$ Hillier et al. (2015) find that individual fixed effects are correlated with observable factors, such as the insider's year of birth, education, and gender, and surmise that these factors are likely related to more fundamental attributes that lead to differences in style. While it is not clear whether observable demographics, such as gender and education, are a measure of an individual's fundamental values (see for example, Babin and Donald 1997; Dato-On et al. 2006), we verify that our measure of legal infractions captures a different construct relative to other observable and unobservable characteristics of senior executives (namely, MBA degree, top MBA degree, gender, overconfidence, materialism, military experience, being born during a recession, starting the career during a recession, narcissism and opportunistic trading). These results are presented in the Internet Appendix.
} 
on being less wealthy, executives with criminal convictions are more likely to time their sales. However, they do not find this effect for wealthy executives. Kallunki et al. (2016) find that Swedish insiders who are noncompliant with tax laws engage in more insider trading.

Our first set of hypotheses concerns the relation between executives’ propensity for informed trade and their psychological type, as captured by their history of legal infractions, and is based on the criminology and psychology literatures. The criminology literature argues that individuals with a greater propensity to commit crimes are likely to have low self-control and are less likely to conform to social norms and laws (Gottfredson and Hirschi 1990). Blickle et al. (2006) argue that low self-control and high hedonism are positively related to the likelihood of committing white-collar crime. Further, individuals displaying unethical tendencies, such as past criminal behavior, tend to persist in this type of behavior (Gendreau et al. 1996). Along these lines, Davidson et al. (2015) document that prior legal infractions are significantly associated with executives’ propensity to commit accounting fraud.

Based on the above research, if the presence/absence of a legal record captures meaningful variation in regard for rules and self-control, we expect that all else equal, executives with a record will earn larger abnormal returns from their trades.

However, this prediction is not without tension. Unlike other outcomes examined in prior research representing extreme cases of misconduct (e.g. financial statement fraud; Davidson et al. 2015), insiders trading their firm's stock is quite common. Further, establishing when an insider uses his private information illegally is difficult. Thus, such behavior can more easily be rationalized due to the fact that what constitutes "material" non-public information and a breach of fiduciary duty can be open to interpretation (Bainbridge 2000). As a result, the degree of 
disregard for rules and self-control needed to rationalize informed trading may be relatively low, mitigating any behavioral differences between recordholder and nonrecordholder executives.

Our next prediction concerns the relation between the profitability of inside trades and the severity of legal infractions. If the severity of legal infractions captures the extent of executives' lack of self-control and disregard for laws, then we expect that trades by individuals with more serious infractions will be associated with higher profits than trades by other recordholders.

Alternatively, it is possible that the underlying psychological construct we are measuring is reflected in any act of breaking the law, even minor ones. For instance, Fisman and Miguel (2007) find that United Nations diplomats' unpaid parking tickets in New York City are significantly related to corruption and legal enforcement in their home country, suggesting that even minor legal infractions can capture differential behavioral norms. Junger et al. (2001) examine the relation between criminal behavior (including violent crimes, vandalism, nonviolent theft, drug crimes) and behavior leading to traffic accidents (such as speeding, right-of-way violations, ignoring traffic signals, illegal passing) and find that risky driving behavior is related to all measures of serious criminal behavior. Specifically, the fact that someone was involved in criminal activity more than doubled the likelihood that he or she would be involved in traffic infractions leading to accidents. In brief, there is evidence of consistency in behavior across different types of delinquents. In fact, the recidivism literature suggests that past behavior is one of the best predictors of future behavior (e.g., Blumstein et al. 1986; Gottfredson and Gottfredson 1985). Individuals with prior (even minor) infractions are more likely to have future infractions and can even escalate to more serious offenses. If the underlying construct of lack of self-control manifests similarly in crimes of varying severity, then we should not find significant differences in the profitability of insider trades depending on the severity of the infraction. 


\subsection{Executive type and the deterrent effect of corporate governance}

Our second set of hypotheses concerns how the effectiveness of governance mechanisms in reducing insider trading varies across executives. Several recent studies examine the relation between insider trading profitability and firms' governance environments. Jagolinzer et al. (2011) document that the general counsel - a key governance mechanism - can effectively mitigate informed trading. Ravina and Sapienza (2010) find that independent directors earn higher trading profits at firms with the "weakest” governance, as proxied by G-score and board size. Dai et al. (2016) find that better governed firms (based on measures of board independence and institutional ownership) have lower insider profits from sales. Considering the Dutch market, Cziraki et al. (2014) find that insider trading profits are actually higher when shareholder rights are stronger (i.e., they are not restricted by anti-shareholder mechanisms, such as preference shares or poison pills). They argue that managers are likely to seek greater insider trading profits when they cannot exploit other private benefits due to stronger shareholder rights. There is also evidence that insider trading profits are associated with the quality of firms' internal control systems (Skaife et al. 2013) and the corruption culture in a firm (Liu 2016). This literature documents the deterrent effect of certain governance mechanisms on insider trading; however, it treats all insiders as homogenous.

If our measure of the presence/absence of a legal record captures meaningful variation in regard for rules and self-control, then we expect recordholder executives to engage in informed trading regardless of the governance mechanisms in place. In particular, we predict that the trading profits of recordholders, in particular serious recordholders, are unaffected by the existence of blackout policies. Alternatively, since the existence of governance mechanisms does raise the cost of insider trading, such mechanisms may equally deter informed trading by all types of executives. 
Note that we do not make a directional prediction for the differential effect of governance mechanisms between recordholders and non-recordholders as we see two possible scenarios. One, if nonrecordholders, on average, do not earn abnormal profits by directly exploiting information advantages, then governance mechanisms will not affect the profitability of their trades and the deterrent effect (if any) of such mechanisms will occur only through recordholders. Two, if nonrecordholders also earn abnormal profits on average (though not necessarily as large as those earned by recordholders), then we expect that the profitability of their trades will be lower in firms with stronger governance. In this case, we would predict that the deterrent effect of governance is greater for nonrecordholders compared to that for recordholders. Ex-ante, we can only make a prediction about the effect of governance mechanisms on the profitability of trades by recordholders, rather than their differential effect between recordholders and non-recordholders.

\section{Sample, data, and descriptive statistics}

We consider all firms on ExecuComp and CRSP during 1986-2017 that are also included on the Thomson Reuters insider trading database for inclusion in our sample. For these firms, we assign executive designations based on Thomson Reuters' Role Codes. Specifically, non-CEO "senior executives" include any C-level executive (chief operating/ financial/ investment/ technology/ marketing/ risk officer), president, executive vice president, senior vice president and general counsel. Data requirements for each transaction include: transaction date, share price, transaction codes (we consider codes P, S, and G; results are robust to excluding code G) and type of trade (purchase or sale). We also collect the number of shares traded and held when available. Consistent with prior research, our analyses only include non-compensation related equity purchases as well as sales of common stock under a Section 16 officer's direct control. 
Our data on executives' legal infractions are obtained from federal and state criminal records databases, where legal infractions include traffic violations, driving under influence of alcohol, drug charges, reckless endangerment, assault, domestic violence and sexual assault. We employ licensed private investigators who verify the accuracy of individual legal infractions using social security numbers. To create our sample, we purchase criminal background checks for CEOs at 450 randomly selected firms with available data. We require that CEOs are listed in Execucomp for at least two years (to avoid interim CEOs). We then purchase background check data for randomly selected non-CEO senior executives at each of these firms and require non-CEOs be listed in Execucomp for at least two years during the CEO's tenure so that we can examine trading within the same firm and over the same time period. In total, we obtain information on criminal records for about 2,000 insiders. To test differences in abnormal trading profits and sensitivity to governance mechanisms across executive type and within firm, we need within firm variation with respect to insider's legal records. In some cases, none of the insiders we purchase data for in a given firm had legal infractions, leaving us with no intra-firm variation to exploit. After eliminating these firms, we are left with a sample of 281 firms (comprising 1,474 executives, including 503 CEOs and 971 non-CEOs) with at least one executive with, and one without, a legal infraction. Our primary results in the paper are reported using this sample with intra-firm variation in infractions. However, our results hold if we analyze all executives in cross-sectional models which do not include firm fixed effects.

For each executive, we set an indicator variable, Record, equal to 1 if the executive has any legal infractions as of December 31, 2017, and 0 otherwise, regardless of when these infractions occur, as long as the executive was at least 30 year old at the time of the infraction. ${ }^{5}$ That is, we

\footnotetext{
${ }^{5}$ We chose 30 years based on the age of the senior executives in our sample and how far back in time we are able to collect legal infractions data.
} 
assume that executive type is stable (at least during the executive's adult life), which is consistent with findings in the criminology literature that individuals displaying past criminal behavior tend to persist in that type of behavior (Gendreau et al. 1996). We also provide support for this assumption in Section 4. We set indicators for Traffic and Serious equal to 1 if an executive has only traffic infractions or has serious infractions (anything other than traffic infractions) respectively, and 0 otherwise (see the Appendix for details on variable definitions).

Table 1 summarizes the sample used in our intra-firm analyses. ${ }^{6}$ Of the 503 CEOs, 188 (37\%) have legal records. Of these 188 CEOs, 55(29\%) have serious infractions. We also observe that 71 (38\%) CEOs have multiple infractions (untabulated analyses indicate that $84 \%$ percent of these CEOs have multiple traffic infractions but no serious offenses).

\section{PLACE TABLE 1 ABOUT HERE}

Following Jagolinzer et al. (2011), we estimate the profitability of a net purchase (net sale) by a given executive $i$ in firm $j$ on day $t$ (Trading Profit $t_{i, t}$ ) using the $\alpha(-\alpha)$ of the four factor Fama-French (1993) and Carhart (1997) model estimated over the 180 days following the transaction:

$$
\left(R_{j, t}-R_{f, t}\right)=\alpha+\beta 1\left(R m k t_{t}-R_{f, t}\right)+\beta 2 S M B_{t}+\beta 3 H M L_{t}+\beta 4 U M D_{t}+e_{t}
$$

where on a given day $t, R_{j, t}$ is the daily return to firm $j$ 's equity, $R_{f, t}$ is the daily risk-free interest rate, $R m k t_{t}$ is the daily CRSP value-weighted market return, $S M B_{t}, H M L_{t}$, and $U M D_{t}$ are the daily size, book-to-market, and momentum factors (Fama and French 1993; Carhart 1997), and $\alpha(-\alpha)$

\footnotetext{
${ }^{6}$ Compared to the Execucomp population, our sample firms have larger market capitalization and sales but similar market-to-book ratios, return on assets, CEO wealth, board independence, and institutional holdings (see Internet Appendix).
} 
is Trading Profit $t_{i, t}$, the average daily risk-adjusted return to a net purchase (sale) during the 180 days following the transaction. ${ }^{7}$

Our primary measure of a firm's governance environment is the existence of a blackout policy prohibiting insiders from trading during specific windows. Several reasons prompt our use of this governance mechanism. First, blackout periods are directly related to regulating insider trades. To discourage trading on material, non-public information, firms themselves restrict their insiders to trading during certain periods, typically following quarterly earnings announcements. Second, there is evidence that blackout periods are quite widespread and effective in constraining insider trades (Bettis et al. 2000; Jeng 1999). For instance, Bettis et al. (2000) document that about $92 \%$ of their sample firms have some form of policy regarding insider trading and $78 \%$ have explicit blackout periods. They find evidence confirming that corporate self-regulation has a significant effect on the rate and profitability of insider trading. Specifically, for firms that have blackout periods, insider trading is concentrated heavily during time windows in which trading is permitted; Bettis et al. (2000, page 202) state that "trading in blackout periods is about three times less likely than trading during allowed trading windows”.

Collecting data on firm's blackout periods is challenging. Bettis et al. (2000) and Jeng (1999) obtain their information by surveying firms, a method that results in small sample sizes and is subject to self-selection biases. As such, we follow the methodology in Roulstone (2003) who measures blackout periods by classifying firms whose insiders overwhelmingly execute their trades after earnings announcements as firms that restrict insider trading. Roulstone notes that this proxy is based on the results in Bettis et al. (2000) and Jeng (1999) regarding timing

\footnotetext{
${ }^{7}$ As pointed out by Jagolinzer et al. (2011), this approach has at least two advantages. First, estimating average daily abnormal returns avoids the biases inherent in statistical tests of long-run buy-and-hold returns, and second, computing trade-day specific risk-adjusted returns relative to the Fama-French model controls for differences in risk across transactions (i.e. transaction-day specific factor loadings) and provides a trade-specific measure of profitability. Results are robust to estimating equation (1) including one and two lags of all factors to correct for infrequent trading and to measuring trading profits using six-month market-adjusted buy-and-hold returns.
} 
restrictions on insider trades. These papers document that the most common restriction is allowing insiders to trade only during a period closely following an earnings announcement one month following the earnings announcement (Jeng 1999) or three through 12 days following the announcement (Bettis et al. 2000). We consider all individual trades by our sample section 16 insiders and merge these trades with the firms’ earnings announcement dates. We classify each trade as being executed during an allowed trading window if it occurs within 21 trading days following an announcement. For each firm we then calculate the percentage of shares traded during these trading windows by all officers and directors as in Roulstone (2003). This percentage - called “Safe” in Roulstone (2003) - represents the percentage of a firm's insider trades over the sample period that occurs during the "safe to trade" short window following the disclosure of earnings. Next, we designate all firm years for which Safe is $75 \%$ or greater as having a policy restricting insider trading through blackout periods. We define our primary variable to represent this policy as Restrict, an indicator variable equal to 1 when Safe is $75 \%$ or greater, and 0 otherwise. . $^{9}$

Table 2 presents summary statistics for insider trading variables for recordholder (including the subcategories of Traffic and Serious) and nonrecordholder CEOs and non-CEO executives, as well as for firm-level variables for sample firms led by recordholder and nonrecordholder CEOs (continuous variables are winsorized at the $1 \%$ and $99 \%$ levels). Across all categories,

\footnotetext{
${ }^{8}$ Roulstone (2003) measures Safe and therefore Restrict in aggregate over his four-year sample while we measure it on an annual basis. Our tests include firm fixed effects and therefore we need within firm variation in Restrict to estimate the models. Further, our sample period is 31 years and many firms will have adopted or amended blackout policies during our sample period. Roulstone measures Restrict annually in sensitivity analysis. He reports a mean value of Safe of $58 \%$ while ours is $49 \%$, so while we have similar values of Safe, it appears we have more intra-firm variability over our sample period.

${ }^{9}$ One potential issue with Restrict is that after the passage of Rule 10b5-1, participating insiders are allowed to trade during blackout periods and may do so strategically (Jagolinzer 2009). To ensure that this is not confounding our results, we verify that our results hold when we analyze trades which took place prior to the initiation of the Rule (October 2000). We have over 15,000 trades made by over 900 insiders in the pre-Rule 10b5-1 period. Additionally, Jagolinzer (2009) notes that for every 10b5-1 purchaser, there are 29 10b5-1 sellers. In other words, 10b5-1 purchases are quite rare. We recompute Restrict using only purchase transactions, virtually none of which are 10b51 trades, and document similar findings. These results are available in the Internet Appendix.
} 
mean and median abnormal profits from purchases are greater than 0 , which is consistent with prior research (e.g., Jagolinzer et al. 2011). However, profits earned by recordholders are significantly higher than those for nonrecordholders. While generally negative (except for CEOs with serious infractions), abnormal profits from sales are also higher for recordholders. Additionally, recordholder executives are significantly more likely to trade during a blackout period and in the 60 days prior to large information events (i.e. prior to 3-day cumulative abnormal returns which are at least 3 standard deviations away from the firm mean). Serious recordholders alone are significantly more likely to file the Form 4 late with the SEC. We find no difference in total compensation or total wealth between recordholder and nonrecordholder executives. As for firm characteristics, the only significant difference is that firms run by recordholder CEOs are smaller, though the difference is not large in economic terms.

\section{PLACE TABLE 2 ABOUT HERE}

Untabulated analyses reveal the following. There is no statistical difference between the average tenures of recordholder and nonrecordholder executives. Executives stay at their firm for an average of 3.5 years after committing their first infraction, and typically those leaving the firm, in particular CEOs, are closer to retirement (age 65). The stock return performance of firms who's CEOs left shortly after their first infraction is not significantly different from firms who's CEOs remained in office after their first infraction. Finally, a CEO is no more likely to be terminated within one or two years following an infraction than at any other time during their tenure (these results are true for both types of recordholders). Collectively, these results reduce the possibility of survivorship bias, i.e., the possibility that recordholder executives that remain in our sample (vs. those who are fired or leave for other reasons) are somehow "better" than average, thereby explaining their higher returns from trading. 


\section{Empirical results: Insider trading profitability and executive type}

To test our first hypothesis, we examine whether executives' trading profits vary with their type. This intra-firm analysis holds constant time-invariant firm-level factors to control for the opportunity to trade on inside information (e.g., the firm's information and control environments). We include year fixed effects to control for any changes over time in the enforcement of insider trading laws or in social norms. We estimate the following OLS regression with firm and year fixed effects:

$$
\text { Trading Profit } t_{i, t}=\beta 0+\beta 1 \text { Record }_{i}+\beta 2 \text { Size }_{j, t}+\beta 3 \text { Market-to-book }_{j, t}+\beta 4 \text { Return }_{j, t}+\varepsilon_{i, t}
$$

Where Trading Profit $t_{i, t}$ is the average daily risk-adjusted return to a net purchase (sale) by executive $i$ during the 180 days following the transaction on day $t(\alpha(-\alpha)$ from equation (1)), and $\operatorname{Record}_{i}$ is an indicator variable equal to 1 if executive $i$ has any legal infractions, and 0 otherwise. While firm fixed effects control for all time invariant firm-level factors, we follow Cohen et al. (2012) and also include firm size, market-to-book ratio and annual stock returns (all measured at the firm's fiscal year end) for each executive $i$ 's firm $j$ in the model. Standard errors are clustered by executive (results are robust to clustering by firm). ${ }^{10}$

Table 3, panel A presents the results for purchases, and Table 3, panel B presents the results for sales. The coefficient on Record for both purchases (panel A; column 1) and sales transactions (panel B; column 1) is significantly greater than zero (at the .01 level) and indicates that executives with a legal record earn $0.0167 \%$ higher risk-adjusted returns per day (incremental returns totaling 3.006\% over 180 days) following purchases and $0.0134 \%$ higher risk-adjusted returns per day (incremental returns totaling 2.412\% over 180 days) following

\footnotetext{
${ }^{10}$ Given that Table 2 indicates no significant differences in the trading behaviors of CEOs and non-CEO senior executives, we do not distinguish between them in our analyses. Nevertheless, as verification, we modify equation (2) to include a CEO indicator and an interaction between the CEO indicator and Record. Our inferences for CEOs are similar to those we find for all senior executives (see Internet Appendix). We also verify our results are robust to including wealth and total compensation as controls. However adding these control variables results in a meaningful loss of observations mainly because these data are not always available for non-CEOs.
} 
sales, relative to nonrecordholder peers in the same firm. ${ }^{11}$ We interpret our results as support for the prediction that recordholder executives have a higher propensity to exploit inside information to earn abnormal profits. ${ }^{12}$

\section{PLACE TABLE 3 PANEL A ABOUT HERE}

\section{PLACE TABLE 3 PANEL B ABOUT HERE}

Regressions with firm and year fixed effects do not produce a meaningful intercept, resulting in a lack of context when interpreting differences in abnormal returns between recordholders and nonrecordholders. Table 2 provides insights regarding this difference (albeit without firm fixed effects) by showing that recordholder CEOs (non-CEOs) earn approximately 32\% (33\%) larger average abnormal returns from purchases and 43\% (46\%) larger average abnormal returns from sales. Additionally, we re-estimate equation (2) excluding year fixed effects (which produces very similar coefficients on Record, Traffic, and Serious). The untabulated results from this alternative intra-firm regression suggest that recordholders earn approximately 39\% (51\%) larger abnormal returns from purchases (sales) relative to nonrecordholders at the same firm. These differences are slightly larger than the raw differences reported in Table 2. These intra-firm regressions also reveal that in terms of average (abnormal) dollars earned per trade (computed as abnormal return times the number of shares traded times the stock price), recordholders earn

\footnotetext{
${ }^{11}$ To provide more evidence on how trading profits of executives vary by type and to further reduce any potential endogeneity concerns, we re-estimate equation (2) for a subset of 82 executive transitions where the type of the executive changed (i.e., a nonrecordholder executive was replaced by a recordholder executive or vice versa). We find that abnormal returns from both purchases and sales are significantly higher for the recordholder executive. These results provide us with additional assurance on the relation between trading profits and recordholder status.

${ }^{12}$ For completeness, we also examine trade size and trade frequency and find that recordholder executives trade a larger percentage of their holdings when selling shares, but there are no differences in trade sizes for purchases or in trading frequency between recordholder and nonrecordholder executives (see Internet Appendix).
} 
approximately $\$ 17,400$ per purchase in the 180 days following the trade while nonrecordholders earn approximately $\$ 7,300$ per purchase over the same timeframe. ${ }^{13}$

As in previous insider trading studies (e.g. Bhattacharya and Marshall 2012), the above dollar amounts are relatively small, especially when compared to the potential costs that insiders may face (reputation costs, financial penalties, potential prison terms). However, while economic theory suggests that an individual will commit a crime only if the expected benefits exceed expected costs (Becker 1968), behavioral economics has shown that human behavior is not perfectly rational (Jolls et al. 1998). Based on his interactions with former executives who are convicted criminals, as well as from psychological, sociological, and historical research, Soltes (2016) shows that white-collar criminals are not merely driven by excessive greed or hubris, nor do they usually carefully calculate the costs and benefits before breaking the law to determine whether it is worth the risk. Furthermore, anecdotal evidence suggests that the SEC has prosecuted insider trading cases involving similarly small magnitudes (for instance, the insider trading charges against Martha Stewart, https:/www.sec.gov/news/press/2003-69.htm). While our average estimates of abnormal profits are not directly comparable to prosecuted cases of insider trading, the relatively small illegal profits insiders earn in certain cases does provide evidence that insider trading is not always easy to reconcile as a rational cost-benefit analysis.

Next, we examine insider trading profitability for different categories of recordholders. In particular, we replace the indicator Record with Traffic (column 2 in Table 3, panels A and B), an indicator variable that equals 1 for executives who have only committed traffic infractions and with Serious (column 3 in Table 3, panels A and B), an indicator variable that equals 1 for

\footnotetext{
${ }^{13}$ Note that all dollar estimates are based on the estimated abnormal returns from our regression models and average share price and trade size for our sample firms and insiders. Unlike returns, dollar profits depend on cash available to make purchases or equity on hand to sell, which can vary independently from returns. As such, these estimates should be interpreted with this caveat in mind.
} 
executives who have committed serious infractions. Both indicators are equal to zero for nonrecordholders. That is, in each regression, we compare only one subcategory of recordholders to all nonrecordholders. Ideally, we would include all subcategories of recordholders in the same regression and test for differences between Traffic and Serious in the same firm. But doing so requires at least one nonrecordholder, one recordholder with only traffic infractions and one with a serious infraction in the same firm that all make either a purchase or a sale. This occurs in only 4 of our sample firms, largely because only $8 \%$ of sample insiders have serious infractions. Nonetheless, our approach allows us to analyze whether higher average abnormal profits for recordholders are increasing in the severity of the infraction, as identified by the subcategories of recordholders. Also, we are still able to compare the coefficients of interest across the two regressions to gain insights into differences in insiders' profits across the two categories.

The results show that the association between trading profits for both purchases and sales is positive and statistically significant for both categories of recordholder executives compared to nonrecordholder executives in the same firm (at the .05 level or better). The result that abnormal returns from purchases and sales are positive and significant for traffic infractions indicates that even relatively minor infractions are associated with an individual's propensity to trade on inside information and thus can measure an individual's disregard for rules and laws (corroborating the inferences in Fisman and Miguel 2007). A comparison of coefficients indicates that the returns from purchases and sales by recordholders with serious infractions are significantly higher than the corresponding returns by insiders with only traffic infractions (Serious > Traffic at the .05 level or better). Further, the coefficient on Serious for purchases (sales) is approximately 2.5 (4.9) times greater than the coefficient on Traffic. Thus, the economic significance of the differences in abnormal returns earned by insiders with serious infractions is quite large. This 
suggests that the severity of infractions may capture a higher degree of disregard for rules/ laws or lack of self-control. ${ }^{14}$

As noted in Section 3, throughout our analyses our maintained assumption is that type is invariant (at least by the time an individual is old enough to hold a senior executive position at a publicly traded firm). As verification, we compare the profits from trades by recordholders before and after they break the law (i.e., before and after they reveal their type) with executive fixed effects. As shown in the Internet Appendix, there is no difference in the trading profits for executives before and after their infractions were committed, supporting our assumption that, as it pertains to trading behavior, observing an executive break the law is a signal of type and not a signal of a change in type. Also, our results continue to hold when we reclassify executives based on their infractions prior to the current year only (to assess the real time application of Record).

\section{Empirical results: Insider trading and governance mechanisms}

\subsection{Executive type and trading profits in firms with blackout periods}

In this section we examine whether the profitability of trades by recordholders varies with proxies for blackout periods in firms, and whether any effect is significantly different for recordholders (including different types of recordholders) vs. nonrecordholders. We estimate the following OLS regression with firm and year fixed effects:

$$
\begin{aligned}
& \text { Trading Profit } \\
& i, t=\beta 0+\beta 1 \text { Record }_{i}+\beta 2 \text { Restrict }_{j, t}+\beta 3 \text { Record }_{i} * \text { Restrict }_{j, t}+\beta 4 \text { Size }_{j, t} \\
& \quad+\beta 5 \text { Market-to-book }_{j, t}+\beta 6 \text { Return }_{j, t}+\varepsilon_{i, t}
\end{aligned}
$$

\footnotetext{
${ }^{14}$ In additional analyses (tabulated in the Internet Appendix), we examine the trading profits of recordholders with multiple infractions (traffic or serious) compared to non-recordholders in the same firm. Multiple infractions could signal a higher degree of disregard for rules/ laws or lack of self-control, as compared to a lone infraction. To examine this, we re-estimate Equation (2) replacing Record with Multiple, an indicator variable equal to 1 if an individual has multiple infractions, and 0 otherwise. Briefly, trading profits for both purchases and sales are positive and statistically significant for executives with multiple infractions, as compared to nonrecordholders in the same firm (at the .05 level or better). The coefficient estimates on Multiple fall between those on Traffic and Serious. Similar to serious recordholders, returns from purchases and sales by executives with multiple infractions are significantly higher than the corresponding returns by insiders with only traffic infractions (at .05 level; the coefficient on Multiple for purchases (sales) is approximately 1.5 (2.1) times greater than the coefficient on Traffic).
} 
The variable Restrict is an indicator equal to 1 if firm $j$ has a blackout policy to govern insider trading in year $t$. All other variables are defined as in Equation. (2).

Table 4 presents the results. Panel A reveals that all recordholder classifications earn larger profits from purchases as compared to nonrecordholders (i.e. the coefficients for Record, Traffic, and Serious are positive and significant at the .05 level or better) in firms without blackout policies. Blackout policies are not associated with trading profits from purchases by nonrecordholders (the coefficient for Restrict is not significant). More relevant to our research question, the interaction term Record * Restrict is negative and significant (at the .05 level), indicating that blackout policies lower the trading profits of recordholder executives relative to nonrecordholder executives. When examining recordholders by type, we continue to find a negative and significant coefficient (at the .01 level) for the interaction term Traffic * Restrict, but not for Serious * Restrict. In other words, blackout policies are associated with lower profits from purchases by executives with minor infractions (relative to nonrecordholders in the same firm), but not from purchases by executives with serious infractions.

\section{PLACE TABLE 4 PANEL A ABOUT HERE}

With respect to sales, similar to purchases, panel B shows that (i) in firms without blackout policies, recordholders (but only those with serious infractions) earn significantly higher trading profits from sales compared to nonrecordholders (i.e. the coefficients for Record and Serious are positive and significant); and (ii) blackout policies are not associated with trading profits from sales by nonrecordholders (the coefficient for Restrict is not significant). As for our research question, the interaction term Record * Restrict is negative and significant (at the .05 level), though it becomes insignificant when examining the two subcategories separately. The lack of significance on the interaction term Traffic * Restrict (p-value: 0.12 ) could be explained by the 
fact that recordholders with minor traffic infractions do not earn significant abnormal profits from sales even in firms without blackout policies. That is, there is not enough informed selling to detect an effect of blackout policies for this subcategory of insiders. The lack of significance on the interaction term Serious * Restrict is consistent with the results for purchases. It does not appear that blackout policies are associated with reduced abnormal profits from sales for executives with serious infractions relative to nonrecordholders.

\section{PLACE TABLE 4 PANEL B ABOUT HERE}

At the bottom of both panels we present p-values for coefficient summations within model and comparisons across models for executives with traffic or serious infractions. The summation of Restrict + Record Type * Restrict denotes that abnormal trading profits for recordholders are different in firms with and without blackout policies. In both panels this summation is statistically significant for all recordholders and those with traffic violations but not for executives with serious violations. Next, the summation Record Type + Record Type * Restrict represents the incremental abnormal profits earned by recordholders (compared to nonrecordholders) in firms with blackout policies. In both panels, this summation is significant for recordholders with serious infractions but not for all recordholders or for executives with traffic infractions. That is, in firms with blackout policies, executives with serious infractions earn larger abnormal profits than nonrecordholders in the same firm, and their abnormal profits are significantly greater than zero.

A comparison across models reveals that executives with serious infractions earn larger abnormal profits than executives with traffic infractions in firms without blackout policies (Serious > Traffic) and that the effect of blackout policies on abnormal profits is significantly different between these groups $($ Restrict + Serious $*$ Restrict $>$ Restrict + Traffic $*$ Restrict $)$ 
when analyzing purchases but not sales. Finally, for both purchases and sales, executives with serious infractions earn larger abnormal profits than executives with traffic infractions in firms with blackout policies (Serious + Restrict + Serious $*$ Restrict $>$ Traffic + Restrict + Traffic $*$ Restrict). ${ }^{15}$

In sum, the evidence in Table 4 suggests that blackout policies do not appear to influence the trading activity of insiders with serious infractions. They earn abnormal profits from both purchases and sales that are not significantly different in firms with and without blackout policies. ${ }^{16}$ However, we do find evidence that blackout policies mitigate informed trade by recordholders with minor infractions. Profits from purchases by recordholders with traffic infractions are significantly lower in firms with blackout policies and are not significantly different than profits earned by nonrecordholders in the same firm. The evidence for sales is more mixed - recordholders with traffic infractions do not earn relative abnormal profits from sales in firms with or without blackout policies but there is evidence that the overall profitability of their sales is lower in firms with blackout policies.

As noted earlier, we measure Restrict annually, where we consider a firm to have a policy restricting insider trading in firm-years where $75 \%$ of the firm's insider trading takes place in the "safe to trade" short window following the disclosure of earnings. As a robustness test, we also

\footnotetext{
${ }^{15}$ The results are economically meaningful as well. For example, when considering purchases, executives with traffic infractions earn $0.0242 \%$ lower risk-adjusted returns per day in firms with blackout policies compared to firms without blackout policies. This difference is $46 \%$ of the mean abnormal profits earned by traffic recordholders that we report in Table 2. Meanwhile, we estimate that executives with serious infractions actually earn $30 \%$ higher abnormal returns in firms with blackout policies than in firms without blackout policies. In dollar terms, traffic recordholders earn an average abnormal profit of \$3,884 per trade in the 180 days following a purchase in firms with blackout policies, which is about 22 percent of the estimated average abnormal profits of $\$ 17,400$ made by recordholders in all firms (see section 4). In comparison, serious recordholders earn \$20,502 per trade in abnormal profits over this same period. For sales, the negative coefficient for Record * Restrict is larger in magnitude than the positive coefficient for Record, suggesting that the reduction in abnormal profits in firms with blackout policies is greater than 100 percent of the abnormal profits in firms without blackout policies.

${ }^{16}$ As before, we repeat our analyses for executives with multiple infractions and find results similar to those we obtain for serious recordholders. Trading profits for executives with multiple infractions are generally insensitive to blackout policies, are higher than those for nonrecordholders in the same firm and are larger than profits earned by traffic recordholders.
} 
re-estimate equation (3) using a modified version of the blackout policy proxy developed in Lee et al. (2014). Specifically, we consider that a firm has a blackout policy once 75 percent of trades in a year take place outside of a blackout period and at least 50 percent of future trades take place outside of a blackout period. ${ }^{17}$ Our results using this alternative measure are similar to those presented in Table 4 and are reported in the Internet Appendix. In untabulated tests, we also verify that our results are robust to using Safe, which is the percentage of trading volume occurring outside of blackout periods (as per Roulstone 2003). However, as firms either have blackout policies or do not, the binary measures probably represent more accurate proxies.

\subsection{Robustness tests: Other governance mechanisms}

Our main governance variable is blackout policies because they directly limit insider trading. In additional analyses we repeat our tests for two other governance proxies based on Dai et al. (2016): (i) monitoring by the board, measured using an indicator variable which equals 1 if the annual percentage of directors who are independent is above the sample median and 0 otherwise, and (ii) monitoring by institutional investors, measured using an indicator variable which equals 1 if the annual percentage of institutional ownership in the firm's stock is above the sample median and 0 otherwise. We measure our governance proxies as binary variables because we estimate interaction terms in our regressions and doing so allows for an economically meaningful interpretation of our coefficients of interest. However, we obtain similar results when we

\footnotetext{
${ }^{17}$ Lee et al. (2014) assume a firm has a blackout policy once 75 percent of trades in a quarter take place outside of a blackout period (outside of the 21 trading days after an earnings announcement) and at least 50 percent of trades in each subsequent quarter take place outside of a blackout period. Their proxy suggests that in $1986,7 \%$ of firms had blackout policies and that the percentage of trades taking place during a non-blackout period was 34\% in 1986 and increased to $57 \%$ by 2010 . When using their method, only $14 \%$ of our firms have blackout policies during the years we have available trades to analyze. Per their method, many of our sample firms implement blackout policies years after the insiders for which we have data leave the firm. Given that our sample is 281 firms, there are too few observations to credibly analyze, particularly firms with insiders with serious infractions. Therefore, we use a modified version of their measure in our robustness test.
} 
measure proxies as continuous variables. We re-estimate the regression represented in equation (3) by replacing Restrict with our measures of board independence or institutional ownership.

Our results and inferences are similar for board independence and institutional ownership and are reported in the Internet Appendix. We highlight key insights here. We obtain a positive and significant coefficient on the recordholder proxies in 11 of 12 regressions, suggesting that recordholders earn abnormal profits relative to nonrecordholders in firms with lower levels of board independence and institutional ownership (the coefficient on Traffic in the model examining sales with below median institutional holdings is the lone exception). The interaction terms between recordholder type and governance proxy are negative and significant when examining all recordholders and those with only traffic infractions, but are not significant when examining recordholders with serious infractions. We interpret these results as evidence that increased monitoring from boards and institutions limits the proclivity of executives with minor infractions to make informed trades relative to nonrecordholders in the same firm. But, as with blackout policies, we fail to find evidence that better governance reduces informed trade for executives with serious infractions. On average, the abnormal profits earned by recordholders with traffic infractions with above median governance are not significantly different than profits earned by nonrecordholders in the same firm. In contrast, the profits earned by executives with serious infractions continue to be higher than nonrecordholders in the same firm.

In summary, the evidence in section 5 implies that while insiders with minor infractions are disciplined by governance mechanisms, including blackout policies, boards of directors and institutional investors, the trading behavior of recordholders with more serious infractions does not appear to be sensitive to these disciplining mechanisms.

\section{Executive type and propensity to trade during certain windows}


The results in sections 4 and 5 suggest that recordholders are more likely to trade on inside information than nonrecordholders, but it is unclear whether these trades are illegal (i.e. based on material private information) or even undesirable. In this section we address this question by examining additional properties of recordholders' trades.

\subsection{Are recordholders more likely to engage in undesirable trading behavior?}

To address this question, we examine whether recordholders are more likely to: (i) engage in trades during a blackout period, and (ii) fail to meet SEC timely reporting requirements.

\subsubsection{Are recordholders more likely to trade (and trade in larger sizes) during blackout periods?}

To address this question we estimate the following conditional logit regression (equation 4(a)) and OLS regression (equation 4(b)) with firm and year fixed effects for the subset of firms we estimate as having a blackout policy:

$$
\begin{gathered}
\text { Blackout Trade }_{i, t}=\beta 0+\beta 1 \text { Record }_{i}+\beta 2 \text { Size }_{j, t}+\beta 3 \text { Market-to-book }_{j, t} \\
+\beta 4 \text { Return }_{j, t}+\varepsilon_{i, t}
\end{gathered}
$$

In Equation (4a) the dependent variable, Blackout Trade, is an indicator variable that equals 1 if a trade was executed during a blackout period (outside of the 21 trading days following a quarterly earnings announcement), and 0 otherwise. In Equation (4b) the dependent variable, Trade Size, is the number of shares traded (in thousands). Given the limited evidence (we are not aware of any studies in the US) on the firm-level determinants of insiders executing trades in blackout periods, we include the same control variables that we use in our trading profits regressions (Size, Market-to-book and Return) to control for the possibility that they may be related to whether executives trade in restricted periods. 
Table 5 presents the results. Panel A reveals that recordholders, specifically those with serious infractions, are significantly more likely to trade during a blackout period compared to nonrecordholders. Marginal effects suggest that recordholders are 7 percent more likely to execute trades during a blackout period than nonrecordholders, with the difference increasing to 21 percent for executives with serious infractions. In contrast, executives with traffic infractions are not more likely to execute blackout trades. Also, serious recordholders are significantly more likely to trade in blackout periods than traffic recordholders (Serious $>$ Traffic).

\section{PLACE TABLE 5 PANEL A ABOUT HERE}

Panel B indicates that, on average, trades made during blackout periods are significantly smaller, both for nonrecordholders and for each category of recordholders (the coefficient on Blackout Trade is always negative and significant as is the summation of Blackout Trade and Record Type * Blackout Trade, at the .05 level or better). However, we fail to find evidence of a within-firm differential effect across recordholders and nonrecordholders both outside the blackout periods (Record, Traffic and Serious are not significantly different from zero) and during blackout periods (Record Type * Blackout Trade is never significantly different from 0). The summation Record Type + Record Type * Blackout Trade - which represents the difference in trade size between recordholder and nonrecordholder executives in blackout periods is not significantly different from 0.

\section{PLACE TABLE 5 PANEL B ABOUT HERE}

A comparison across models indicates that trades made by serious recordholders are larger than trades made by traffic recordholders. This is true both in non-blackout periods (Serious > Traffic) and during blackout periods (Serious + Blackout Trade + Serious * Blackout Trade $>$

Traffic + Blackout Trade + Traffic * Blackout Trade). Also, the effect of blackout periods on 
trade size does not differ between serious and traffic recordholders (test of Blackout Trade + Serious * Blackout Trade $>$ Blackout Trade + Traffic * Blackout Trade not significantly different from zero).

Overall, the results in Table 5 indicate that recordholders (particularly serious recordholders) are more likely to trade during blackout periods; however, blackout trades are smaller for all sample insiders (perhaps to avoid additional scrutiny). Further, trade size does not vary across recordholder and nonrecordholder executives.

\subsubsection{Are recordholders more likely to report their trades late with the SEC?}

We examine the timing of insider trading reports (Form 4) filed by executives based on their type. Specifically, we examine whether recordholders are more likely to report their trades later than SEC deadlines. For this purpose, we split the sample period into before August 29, 2002 when corporate insiders were required to report their trades no later than the 10th day of the next calendar month - and after August 29, 2002 - when, after the passage of the Sarbanes Oxley Act, this requirement was shortened to 2 trading days after the trade is executed. Specifically, we estimate the following conditional logistic regression with firm and year fixed effects:

$$
\begin{array}{r}
\text { Late Filing }_{i, t}=\beta 0+\beta 1 \text { Record }_{i}+\beta 2 \text { Size }_{j, t}+\beta 3 \text { Market-to-book }_{j, t}+ \\
\beta 4 \text { Return }_{j, t}+
\end{array}
$$

The dependent variable, Late Filing, is an indicator variable equal to 1 if Form 4 was filed late, and 0 otherwise (Harvison, 2018). All other variables are as defined before.

Table 6 presents the results for trades executed in the two reporting regimes. In both periods serious recordholders are more likely to file Form 4 late. However, we find no evidence that recordholders with only minor infractions file Form 4 late. Perhaps not surprisingly, in both filing periods, recordholders with serious infractions are more likely to file late compared to recordholders with only traffic infractions (Serious > Traffic in both periods). Additionally, in 
untabulated analyses, we find that, conditional on filing late, serious recordholders file the Form 4 significantly later than nonrecordholders in the same firm, as well as later than traffic recordholders. In particular, pre (post) August 29, 2002, serious recordholders' late filings occur nine (four) days later on average than other insiders in the same firm.

\section{PLACE TABLE 6 ABOUT HERE}

\subsection{Are recordholders' trades more likely based on material, non-public Information?}

We conduct the following tests to shed light on whether recordholders' trades are more likely to be based on material, non-public information. We examine: (i) whether recordholders are more likely to trade prior to large information events (under the assumption that such trades are more likely to be based on their private information), and as a special case, study the trading behavior of recordholders in the years preceding bankruptcy filings, and (ii) whether recordholders' trades contain greater information regarding future returns.

\subsubsection{Trades prior to large information events}

We first examine whether recordholders are more likely to execute trades prior to large information events. To identify large information events, we compute non-overlapping 3-day cumulative abnormal returns (CARs) for sample firms over the sample period, and then for each firm identify CARs that are at least 3 standard deviations from the firm's mean CAR, hereafter “large CARs” (results are robust to using 4 standard deviations; see Internet Appendix). To make sure we are identifying large information events, we eliminate large CARs for which we cannot identify a significant information event from media articles collected from Factiva over the 40day window from $t-10$ to $t+30$ following the CAR's end date. ${ }^{18}$ We estimate the following conditional logistic regression with firm and year fixed effects:

\footnotetext{
${ }^{18}$ This results in eliminating $16 \%$ of CARs. Results are not sensitive to their exclusion. The following events were discussed in media articles following CARs: earnings announcements and forecasts ( $21 \%$ of CARs); mergers,
} 
$C A R$ Trade $_{i, t}=\beta 0+\beta 1$ Record $_{i}+\beta 2$ Size $_{j, t}+\beta 3$ Market-to-book $_{j, t}+\beta 4$ Return $_{j, t}+\varepsilon_{i, t}$

In the above model, CAR Trade is an indicator variable equal to 1 for purchases (sales) that occur before large price increases (decreases), and 0 otherwise and all other variables are as defined earlier. We measure CAR Trade considering trades that take place within the 60 days preceding large CARs (results are robust to using 30 days; see Internet Appendix).

Table 7 presents the results. Recordholders as a group, traffic recordholders and serious recordholders are all significantly more likely than nonrecordholders to execute trades 60 days prior to large CARs. The marginal effects indicate that recordholders (traffic; serious) are approximately 11 percent ( 8 percent; 16 percent) more likely to execute a trade before a large CAR. The coefficient on Serious is significantly larger than that on Traffic.

\section{PLACE TABLE 7 ABOUT HERE}

\subsubsection{The case of corporate bankruptcy}

As a specific example of trading prior to a large information event, we study the trading behavior of recordholder and nonrecordholder CEOs during the 3-year period prior to the bankruptcy filing date for a random sample of 110 CEOs at 106 firms (4 firms had dual CEOs). ${ }^{19}$ Previous studies provide evidence of insider selling up to 5 years before the bankruptcy filing date (Bradley and Seyhun 1997). If recordholder executives have a higher propensity to trade on material private information, then we expect they will be more likely to sell (or reduce net purchases) shares before the stock-price declines that occur after filing for bankruptcy.

acquisitions, divestitures, or joint ventures (14\%); stock or debt offerings, dividends, or buybacks (12\%); credit or analyst ratings (11\%); development of technologies (9\%); increasing or decreasing investments (9\%); changes in management (8\%); litigation (7\%); and regulation and other events (9\%).

${ }^{19}$ We thank Ryan Ball for providing the data on bankrupt firms from 1996 through 2008. Given the cost of acquiring background checks, we only acquired data on legal infractions for CEOs in these firms. We do not include these 106 firms in our main tests as we only acquired data for one executive in each firm and to avoid making generalizations from a sample with a disproportionate number of firms approaching bankruptcy. Note that this sample consists of 22 recordholder CEOs and 88 nonrecordholder CEOs and results should be interpreted keeping this small sample in mind. 
Table 8, panel A reveals that on average, recordholder CEOs were net sellers of 1,622,263 shares in the 3-year period before bankruptcy, versus only 84,882 net sales for nonrecordholder CEOs (a significant difference at the .05 level). The difference is unique to this period: in the previous 3-year window (from month 72 to month 36 prior to bankruptcy), recordholder CEOS were net buyers of 698,866 shares, while nonrecordholder CEOs were net sellers.

\section{PLACE TABLE 8 PANEL A ABOUT HERE}

Next, we estimate the following OLS regression for abnormal profits from sales by CEOs:

$$
\text { Trading Profit } t_{i, t}=\beta 0+\beta 1 \text { Record }_{i}+\beta 2 \text { Size }_{j, t}+\beta 3 \text { Market-to-book }{ }_{j, t}+\beta 4 \text { Return }_{j, t}+\varepsilon_{i, t}
$$

The dependent variable is abnormal trading profits from sales by CEOs. We estimate equation (7) separately for the 3-year period prior to bankruptcy, and the previous, adjacent 3-year period. We do not include firm fixed effects because we have only one executive per firm.

Table 8, panel B presents the results. The coefficient on Record is statistically significant (at the .01 level) in the 3-year period prior to bankruptcy. During this period recordholder CEOs earn $0.122 \%$ higher risk-adjusted returns per day (incremental returns totaling 21.96\% over 180 days) following sales as compared to nonrecordholder CEOs. ${ }^{20}$ Recordholder CEOs do not earn higher risk-adjusted returns in the previous, adjacent 3-year period. The coefficient on Record remains positive but is no longer significant when we repeat the analysis for the 2- or 1-year period prior to bankruptcy, likely because of the lower number of trades and therefore lower power of the test.

\section{PLACE TABLE 8 PANEL B ABOUT HERE}

Overall, while not conclusive, the combined evidence in this section suggests that trades executed by recordholder executives are more likely based on material non-public information.

\footnotetext{
${ }^{20}$ While the economic magnitudes of these results are relatively large, it is important to note they are driven by a small number of trades (264 trades within the 3-year period prior to bankruptcy) and that price declines for many firms just before or after bankruptcy are also large.
} 


\subsubsection{Do recordholders' trades better predict future returns?}

If recordholders more often trade based on material, non-public information, then such trades should contain greater information regarding future returns. We analyze trades’ predictive ability by examining the returns to portfolios for both recordholder and nonrecordholder executives. Following the approach taken in Cohen et al. (2012), we identify trades in a given month and then construct buy, sell and (buy-sell) portfolios containing these stocks, and examine the returns to the portfolios of recordholder and nonrecordholder trades over the following month. Portfolios are rebalanced each month based on new trades. ${ }^{21}$

Table 9 presents the risk-adjusted portfolio returns for the Fama-French three factor model for all buys, all sells, and all (buys-sells) for recordholder and nonrecordholder executives. ${ }^{22} \mathrm{~A}$ long-short portfolio following buys-sells earns significant abnormal returns for both types of executives; these returns are significantly larger (at the .05 level) for the portfolio of recordholder executives. A portfolio that is long in recordholder buys and short in recordholder sells earns a Fama-French alpha of 221 basis points per month $(t-s t a t=3.40)$ and an annualized alpha of 2,652 basis points. The corresponding Fama-French alphas for nonrecordholder (buyssells) is 105 basis points monthly (t-stat $=2.94$ ) and 1,260 basis points annually. The difference in these returns between recordholder and nonrecordholders is statistically significant: the portfolio following recordholders earns 116 monthly and 1,392 annualized basis points more than that following nonrecordholders $(\mathrm{t}$-stat $=2.34)$. Further, while buys for both recordholder and nonrecordholders earn significant abnormal returns, only recordholder sales earn significant

\footnotetext{
${ }^{21}$ We do not present results in this table by recordholder type, as monthly rebalancing of portfolios is difficult in these cases. In finer splits, there are many months with buys and no sells, sells and no buys, or no trades at all, and the buys-sells portfolio is not comparable to the individual buy or sell portfolios or across executive by type.

${ }^{22}$ The results reported are for equal weighted portfolios; we obtain similar results using value weighted portfolios. Our results are also robust to controlling for the routine vs. opportunistic trader status of our executives based on the classification developed in Cohen et al. (2012).
} 
abnormal returns. These results suggest that recordholders' trades better predict future returns, consistent with such trades more likely being based on non-public, material information.

\section{PLACE TABLE 9 ABOUT HERE}

\section{Why do boards hire recordholder executives?}

The findings in this paper raise the following question: why do boards hire, or not fire, executives who break the law?

One potential explanation is that directors in firms with recordholder CEOs are less independent (in form or substance) from the CEO, and thus more likely to ignore legal infractions when deciding to hire or retain (not fire) the CEO ${ }^{23}$ However, the proportion of independent directors is not significantly different between firms with recordholder CEOs and with nonrecordholder CEOs (mean: $71 \%$ vs. $72 \%$ ). Also, directors in firms with recordholder CEOs do not have more social ties (i.e., overlaps in educational institutions, military, social clubs, or past employment) with the CEO vs. those in firms with nonrecordholder CEOs (mean: $35 \%$ vs. $30 \%)$.

A second possibility is that directors in firms with recordholder CEOs are also more likely to be recordholders ("like attracts like"), relative to directors in firms with nonrecordholder CEOs, and thus are more forgiving of the CEO's past legal infractions. Obtaining data on the criminal records of all directors for our sample firms would be prohibitively costly. However, we provide indirect evidence as follows. Given the earlier evidence that recordholders earn larger profits from inside trades, if independent directors of firms with recordholder CEOs were more likely to be recordholder themselves, they should exhibit higher trading profits relative to independent directors in firms without recordholder CEOs. However, we fail to find any significant difference

\footnotetext{
${ }^{23}$ This would be the case if recordholder CEOs were systematically more able to influence board composition than nonrecordholder CEOs, which is not immediately obvious.
} 
in trading profits between these two groups. Average abnormal profits earned by independent directors from purchases (sales) in firms with recordholder CEOs equal 0.038 (-0.032) and equal $0.035(-0.031)$ in firms with nonrecordholder CEOs.

A third possibility is that recordholders are executives with superior ability and thus boards are willing to turn a blind eye when it comes to their legal records. However, there are no significant differences in stock return performances across firms with and without recordholder CEOs over their tenures (mean stock returns: 0.20 vs. 0.18; also see Table 2).

In sum, we cannot conclusively determine why boards seem ambivalent towards their executives' legal infractions. It is useful to note that most sample executives' first infraction (67\% of CEOs and $68 \%$ of non-CEOs) occurs after they are hired by the firm. Given the executives are already in the firm, it is possible that boards are less likely to track (or more likely to ignore) legal infractions (especially minor infractions) if the executive is otherwise delivering satisfactory performance. Indeed, informal conversations with several senior executives and directors revealed that many of them do not care about minor infractions (or even somewhat serious transgressions if they were committed reasonably long ago) when hiring executives, and do not put much weight on these factors for existing executives who are otherwise good performers. If this is the case, the evidence in this and other studies should act as a warning for boards about the potential negative consequences of ignoring executives' legal records or assuming that certain governance mechanisms may prevent those negative consequences.

\section{Summary and conclusions}

We provide evidence that the deterrent effect of governance mechanisms to limit insider trading varies across executives within the same firm based on their criminal record. The riskadjusted stock returns following share purchases and sales by recordholder senior executives 
(those who have broken the law) are significantly higher than the risk-adjusted returns following purchases and sales by other senior executives at the same firms. The magnitude of returns is increasing in the severity of the infraction. Given our inclusion of firm and year fixed effects, we infer that recordholder executives, particularly those with serious infractions, have a relatively high propensity to exploit inside information.

Next, while stronger governance, as measured by blackout policies, lowers the abnormal profits made by executives with traffic infractions, such policies do not appear to affect the abnormal profits of executives who have serious legal infractions (as compared to profits of nonrecordholders). Executives with serious infractions are also more likely to trade during blackout periods, report their trades to the SEC late, and trade before large information events.

Our paper is among the early research that documents how the effectiveness of governance mechanisms varies across executives within the same firm. This evidence may be useful to boards of directors and regulators when considering governance mechanisms to monitor and prevent undesirable executive behavior. Our results raise the issue of whether and how the deterrent effect of governance may vary across executives in other corporate contexts and opens up new research opportunities. Subsequent research may also examine whether (and how) boards respond to public scandals (such as the \#MeToo movement) by modifying their governance mechanisms and/or executive selection and retention procedures. 


\section{References}

Babin, L., and R. Donald. 1997. Making sense of the research on gender and ethics in business: A critical analysis and extension. Business Ethics Quarterly 7, 61-90.

Bainbridge, S., 2000. Insider Trading Encyclopedia of Law and Economics III. Edward Elgar Publishing, Cheltenham, U.K.

Becker, C. 1968. Crime and punishment: An economic approach. Journal of Political Economy 76, 169-217.

Bereskin, F., T. Campbell, and S. Kedia. 2014. Philanthropy, corporate culture and misconduct. Working Paper, University of Delaware.

Bettis, C., J. Coles, and M. Lemmon. 2000. Corporate policies restricting trading by insiders. Journal of Financial Economics 57, 191-220.

Bhattacharya, U., and C. Marshall. 2012. Do they do it for the money? Journal of Corporate Finance 18, 92-104.

Blickle, G., A. Schlegel., and P. Fassbender. and Klein, U., 2006. Some personality correlates of business white collar crime. Applied Psychology: An International Review 55, 220-233.

Blumstein, A., J. Cohen, J. Roth, and C. Visher. 1986. Criminal Careers and "Career Criminals.” Vol. 1. Washington, D.C.: National Academy Press, 1986.

Bradley, M., and H. Seyhun. 1997. Corporate bankruptcy and insider trading. Journal of Business 70, 189-216.

Carhart, M., 1997. On persistence in mutual fund performance. Journal of Finance 52, 57-82.

Cheng, Q., and K. Lo. 2006. Insider trading and voluntary disclosures. Journal of Accounting Research 44, 815-848.

Chung, R., M. Firth., and J. Kim. 2002. Institutional monitoring and opportunistic earnings management. Journal of Corporate Finance, 8, 29-48.

Cohen, L., C. Malloy, and L. Pomorski. 2012. Decoding inside information. The Journal of Finance 67, 1009-1043.

Coles, J., N. Daniel, and L. Naveen. 2008. Boards: Does one size fit all? Journal of Financial Economics 87, 329-356.

Coles, J., N. Daniel, and L. Naveen. 2013. Calculation of compensation incentives and firmrelated wealth using Execucomp: Data, program and explanation. Working Paper, https://papers.ssrn.com/sol3/papers.cfm?abstract_id=2296381 
Cziraki, P., P. De Goeji, and L. Renneboog. 2014. Corporate governance rules and insider trading profits. Review of Finance, 18, 67-108.

Dai, L., R. Fu, J. Kang, and I. Lee. 2016. Corporate governance and the profitability of insider trading. Journal of Corporate Finance, 40, 235-253.

Dato-on, M., R. Ingram, and C. McCabe. 2006. The business of ethics and gender. Journal of Business Ethics 64, 101-116.

Davidson, R., A. Dey, and A. Smith. 2015. Executives’ “off-the-job” behavior, corporate culture and financial reporting risk. Journal of Financial Economics 117, 5-28.

Dey, A. 2008. Corporate governance and agency conflicts. Journal of Accounting Research. 46, 1143-1181.

Dittman, I, and E. Maug. 2007. Lower salaries and no options? On the optimal structure of executive pay. Journal of Finance 62, 303-343.

Epstein, S., and E. O’Brien. 1985. The person-situation debate in historical and current perspective. Psychological Bulletin 98, 513-537.

Fama, E., and K. French. 1993. Common risk factors in the returns on stocks and bonds. Journal of Financial Economics 33, 3-56.

Fisman, R., and E. Miguel. 2007. Corruption, norms, and legal enforcement: Evidence from UN diplomatic parking tickets. Journal of Political Economy 115, 1020-1048.

Gendreau, P., T. Little, and C. Goggin. 1996. A meta-analysis of the determinants of adult offender recidivism. Criminology 34, 575-607.

Gottfredson, D., and S. Gottfredson. 1985. Decision Making in Criminal Justice. New York, Plenum Press.

Gottfredson, M., and T. Hirschi. 1990. A General Theory of Crime. Stanford University Press.

Guiso, L., P. Sapienza, and L. Zingales. 2015. The value of corporate culture. Journal of Financial Economics 117, 60-76.

Ham, C., N. Seybert, and S. Wang. 2017. Narcissism is a bad sign: CEO signature size, investment, and performance. Review of Accounting Studies, 1-31.

Hartzell, J., and L. Starks. 2003. Institutional investors and executive compensation. The Journal of Finance, 58, 2351-2374.

Harvison, T. 2018. Political connections and insider trading. Working Paper, University of Arizona. 
Hillier, D., A. Korczak, and P. Korczak. 2015. The impact of personal attributes on corporate insider trading. Journal of Corporate Finance 30, 150-167.

Huddart, S., B. Ke, and C. Shi. 2007. Jeopardy, non-public information, and insider trading around SEC 10-K and 10-Q filings. Journal of Accounting \& Economics 43, 3-36.

Jagolinzer, A. 2009. SEC Rule 10b5-1 and insiders' strategic trade. Management Science 55, 224-239.

Jagolinzer, A., D. Larcker, and D. Taylor. 2011. Corporate governance and the information content of insider trades. Journal of Accounting Research 49, 1249-1274.

Jeng, L. 1999. Corporate insiders and the window of opportunity. Working paper, Boston University.

Jolls, C., C. Sunstein, R. Thaler. 1998. A behavioral approach to law and economics. Stanford Law Review 50, 1471-1550.

Junger, M., R. West, and R. Timman. 2001. Crime and risky behavior in traffic: An example of cross-situational consistency. Journal of Research in Crime and Delinquency 38.4, 439-459.

Kallunki, J., J. Mikkonen, H. Nilsson, and H. Setterberg. 2016. Tax noncompliance and insider trading. Journal of Corporate Finance 36, 157-173.

Kallunki, J., J. Kallunki, H. Nilsson, and M. Puhakka. 2018. Do an insider's wealth and income matter in the decision to engage in insider trading? Journal of Financial Economics 130, 135165.

Ke, B., S. Huddart, and K. Petroni. 2003. What insiders know about future earnings and how they use it: Evidence from insider trades. Journal of Accounting and Economics 35, 315-46.

Knyazeva, A., D. Knyazeva, and R. Masulis. 2013. The supply of corporate directors and board independence. Review of Financial Studies 26, 1561-1605.

Lakonishok, J., and Lee, I., 2001. Are insider trades informative? Review of Financial Studies 14, 79-111.

Lee, I., M. Lemmon, Y. Li, and J. Sequeira. 2014. Do voluntary corporate restrictions on insider trading eliminate informed insider trading? Journal of Corporate Finance 29, 158-178.

Lin, J., and J. Howe. 1990. Insider trading in the OTC market. The Journal of Finance 45, 12731284.

Liu, X. 2016. Corruption culture and corporate misconduct. Journal of Financial Economics 122, 307-327. 
Mischel, W., and P. Peake. 1982. Beyond déjà vu in the search for cross-situational consistency. Psychological Review 89.6, 730-755.

Pervin, L. 1989. Persons, situations, interactions: The history of a controversy and a discussion of theoretical models. Special Issue: Theory Development Forum. Academy of Management Review 14, 350-360.

Pervin, L. 1994. A critical analysis of current trait theory. Psychological Inquiry 5, 103-13.

Ravina, E., and P. Sapienza. 2010. What do independent directors know? Evidence from their trading. Review of Financial Studies 23, 962-1003.

Reuters Business News, 2016. After setbacks, N.Y prosecutors resume insider trading crackdown, https://www.reuters.com/article/us-usa-insidertrading-idUSKCN0Z915C.

Rosenstein, S., and J. Wyatt. 1990. Outside directors, board independence and shareholder wealth. Journal of Financial Economics, 26, 175-191.

Roulstone, D. 2003. The relation between insider-trading restrictions and executive compensation. Journal of Accounting Research 3, 525-551.

Schoar, A. and L. Zuo. 2017. Shaped by booms and busts: How the economy impacts CEO careers and management styles. Review of Financial Studies 30, 1425-1456.

Skaife, H., D. Veenman, and D. Wangerin. 2013. Internal control over financial reporting and managerial rent extraction: Evidence from profitability of insider trading. Journal of Accounting and Economics 55, 91-110.

Soltes, E. 2016. Why they do it: Inside the mind of the white collar criminal. Public Affairs, NY. 
TABLE 1

Sample composition

\begin{tabular}{|c|c|c|}
\hline $\begin{array}{l}\text { Sample } \\
\text { Firms in Compustat/CRSP } \\
1986-2017\end{array}$ & & \\
\hline $\begin{array}{ll}\text { Executives: CEOs } \\
\\
\text { Non-CEO Senior Executives }\end{array}$ & & \\
\hline $\begin{array}{l}\text { Summary of CEOs' and Non-CEO } \\
\text { Senior Executives' Off-the-Job Legal } \\
\text { Records }\end{array}$ & CEOs & $\begin{array}{l}\text { Non-CEO Senior } \\
\text { Executives }\end{array}$ \\
\hline $\begin{array}{l}\text { Executives with any legal infraction } \\
\text { (traffic violations, domestic violence, } \\
\text { reckless behavior, assault, DUI, drug } \\
\text { related charges, sexual assault) } \\
\text { All legal infractions }\end{array}$ & 340 & 398 \\
\hline $\begin{array}{l}\text { Executives with traffic infractions } \\
\text { All traffic infractions }\end{array}$ & $\begin{array}{l}133 \\
269\end{array}$ & $\begin{array}{l}185 \\
320\end{array}$ \\
\hline $\begin{array}{l}\text { Executives with serious infractions (all } \\
\text { but traffic infractions) } \\
\text { All serious infractions }\end{array}$ & 55 & 58 \\
\hline Executives with multiple infractions & 71 & 99 \\
\hline
\end{tabular}

This table summarizes the number of firms and executives included in our sample. There are more CEOs than firms in the sample because most firms had a CEO transition over our sample period. The table also describes the executives in our sample who file Form 16 with the SEC. We define executive designations based on the Role Codes that Thomson-Reuters uses in its insider trading database. The non-CEO senior executive titles in our sample include: Chief Operating Officer, Chief Financial Officer, Chief Investment Officer, Chief Technology Officer, Chief Marketing Officer, Chief Risk Officer, President, Executive Vice President, Senior Vice President, and General Counsel. The table also presents the composition of executives’ legal infractions. 
TABLE 2

Summary statistics

\begin{tabular}{|c|c|c|c|c|c|c|c|c|}
\hline & \multicolumn{8}{|c|}{ CEO VARIABLES } \\
\hline & \multicolumn{2}{|c|}{$\begin{array}{c}\text { Recordholder } \\
\text { CEOs }\end{array}$} & \multicolumn{2}{|c|}{$\begin{array}{c}\text { Traffic Recordholder } \\
\text { CEOs }\end{array}$} & \multicolumn{2}{|c|}{$\begin{array}{c}\text { Serious } \\
\text { Recordholder CEOs }\end{array}$} & \multicolumn{2}{|c|}{ Nonrecordholder CEOs } \\
\hline & Mean & Median & Mean & Median & Mean & Median & Mean & Median \\
\hline Trading Profits: Purchases & $0.058 * * *$ & $0.051 * * *$ & $0.052 * * *$ & $0.043^{* * *}$ & $0.078 * * *$ & $0.074 * * *$ & 0.044 & 0.027 \\
\hline Trading Profits: Sales & $-0.024 * * *$ & $-0.020 * *$ & $-0.035 *$ & -0.027 & $0.014^{* * *}$ & $0.003 * * *$ & -0.420 & -0.030 \\
\hline Trade Size: Purchases & 19.46 & 0.71 & 16.71 & 0.61 & 28.09 & 1.37 & 21.87 & 0.81 \\
\hline Trade Size: Sales & 47.87 & 14.00 & 43.72 & 11.18 & 57.99 & 19.28 & 55.76 & 18.00 \\
\hline Trade Frequency: & & & & & & & & \\
\hline Purchases & 2.09 & 1.00 & 2.16 & 1.02 & 1.83 & 0.95 & 3.16 & 1.06 \\
\hline Trade Frequency: Sales & 5.74 & 2.39 & 5.81 & 2.42 & 5.44 & 2.30 & 5.40 & 2.19 \\
\hline Blackout trade & $0.31 * * *$ & 0.00 & $0.28 * *$ & 0.00 & $0.35 * * *$ & 0.00 & 0.25 & 0.00 \\
\hline Late Filing: pre 8/29/02 & 0.33 & 0.00 & 0.32 & 0.00 & $0.45 * *$ & 0.00 & 0.33 & 0.00 \\
\hline Late Filing: post 8/29/02 & 0.36 & 0.00 & 0.34 & 0.00 & $0.50 * *$ & 0.00 & 0.35 & 0.00 \\
\hline CAR Trade & $0.15^{* * *}$ & 0.00 & $0.13^{* *}$ & 0.00 & $0.17 * * *$ & 0.00 & 0.10 & 0.00 \\
\hline Total Compensation & 6.81 & 3.80 & 6.83 & 3.81 & 6.75 & 3.78 & 7.23 & 3.97 \\
\hline
\end{tabular}


TABLE 2 contd.

Summary statistics

\begin{tabular}{|c|c|c|c|c|c|c|c|c|}
\hline & \multicolumn{8}{|c|}{ NON-CEO SENIOR EXECUTIVE VARIABLES } \\
\hline & \multicolumn{2}{|c|}{$\begin{array}{l}\text { Recordholder } \\
\text { non-CEOs }\end{array}$} & \multicolumn{2}{|c|}{$\begin{array}{c}\text { Traffic Recordholder } \\
\text { non-CEOs }\end{array}$} & \multicolumn{2}{|c|}{$\begin{array}{c}\text { Serious } \\
\text { Recordholder } \\
\text { non-CEOs } \\
\end{array}$} & \multicolumn{2}{|c|}{$\begin{array}{c}\text { Nonrecordholder } \\
\text { non-CEOs }\end{array}$} \\
\hline & Mean & Median & Mean & Median & Mean & Median & Mean & Median \\
\hline & $(1)$ & $(2)$ & $(3)$ & $(4)$ & $(5)$ & $(6)$ & $(9)$ & $(10)$ \\
\hline Trading Profits: Purchases & $0.056 * * *$ & $0.048 * * *$ & $0.052 * * *$ & $0.044 * * *$ & $0.063 * * *$ & $0.058 * * *$ & 0.042 & 0.027 \\
\hline Trading Profits: Sales & $-0.020 * * *$ & $-0.013^{* *}$ & $-0.025^{*}$ & -0.015 & $-0.011^{* *}$ & $-0.009 *$ & -0.037 & -0.020 \\
\hline Trade Size: Purchases & 7.85 & 0.38 & 8.11 & 0.40 & 7.36 & 0.35 & 10.72 & 0.43 \\
\hline Trade Size: Sales & 28.96 & 8.73 & 22.13 & 7.07 & $49.86 * *$ & 10.00 & 29.42 & 6.65 \\
\hline \multicolumn{9}{|l|}{ Trade Frequency: } \\
\hline Purchases & 4.51 & 1.17 & 4.48 & 1.16 & 4.62 & 1.20 & 5.17 & 1.01 \\
\hline Trade Frequency: Sales & 4.92 & 1.77 & 4.89 & 1.77 & 5.00 & 1.82 & 5.20 & 1.99 \\
\hline Blackout trade & $0.30 * * *$ & 0.00 & 0.28 & 0.00 & $0.35 * * *$ & 0.00 & 0.25 & 0.00 \\
\hline Late Filing: pre 8/29/02 & 0.30 & 0.00 & 0.30 & 0.00 & $0.39 *$ & 0.00 & 0.32 & 0.00 \\
\hline Late Filing: post 8/29/02 & 0.34 & 0.00 & 0.33 & 0.00 & $0.45 * *$ & 0.00 & 0.36 & 0.00 \\
\hline CAR Trade & $0.15^{* * *}$ & 0.00 & $0.13^{* *}$ & 0.00 & $0.16^{* * *}$ & 0.00 & 0.10 & 0.00 \\
\hline Total Compensation & 3.29 & 1.71 & 3.27 & 1.70 & 3.35 & 1.73 & 3.49 & 1.79 \\
\hline \multirow[t]{5}{*}{ Wealth } & 7.33 & 7.20 & 7.31 & 7.18 & 7.36 & 7.25 & 7.26 & 7.15 \\
\hline & \multicolumn{8}{|c|}{$\begin{array}{c}\text { FIRM-LEVEL VARIABLES } \\
\end{array}$} \\
\hline & \multicolumn{2}{|c|}{$\begin{array}{l}\text { Firms led by } \\
\text { Recordholder } \\
\text { CEOs } \\
\end{array}$} & \multicolumn{2}{|c|}{$\begin{array}{c}\text { Firms led by Traffic } \\
\text { Recordholder } \\
\text { CEOs }\end{array}$} & \multicolumn{2}{|c|}{$\begin{array}{c}\text { Firms led by Serious } \\
\text { Recordholder } \\
\text { CEOs }\end{array}$} & \multicolumn{2}{|c|}{$\begin{array}{c}\text { Firms led by } \\
\text { Nonrecordholder } \\
\text { CEOs }\end{array}$} \\
\hline & Mean & Median & Mean & Median & Mean & Median & Mean & Median \\
\hline & $(1)$ & $(2)$ & $(3)$ & $(4)$ & $(5)$ & $(6)$ & $(9)$ & $(10)$ \\
\hline Size & $7.75 * * *$ & $7.68 * *$ & $7.80^{* *}$ & $7.72 * *$ & $7.20 * * *$ & $7.19 * * *$ & 7.91 & 7.78 \\
\hline Market-to-book & 3.00 & 2.25 & 2.96 & 2.25 & 3.26 & 2.25 & 3.11 & 2.33 \\
\hline Return & 0.19 & 0.14 & 0.18 & 0.14 & $0.21^{*}$ & 0.15 & 0.18 & 0.13 \\
\hline Restrict & 0.29 & 0.00 & 0.29 & 0.00 & 0.28 & 0.00 & 0.29 & 0.00 \\
\hline
\end{tabular}

This table presents the mean and median values of key insider trading variables for CEOs and non-CEO senior executives based on their type. This table also presents firm-level variables for firms led by recordholder (including traffic and serious) CEOs and nonrecordholder CEOs. All variables are defined in the Appendix. The statistical significance of differences in the values for each recordholder type (all, traffic, and serious) compared to nonrecordholders are denoted next to the corresponding recordholder categories. $* * *, * *$, and $*$ denote statistical significance at the $.01, .05$, and .10 levels respectively. 
TABLE 3

Panel A: Intra-firm analysis: recordholder classifications and abnormal trading profits from purchases

\begin{tabular}{l|ccc}
\hline & \multicolumn{3}{|c}{ Purchases } \\
\hline & Record & Traffic & Serious \\
\cline { 2 - 4 } & $(1)$ & $(2)$ & $(3)$ \\
\hline Record & $0.0167^{* * *}$ & & \\
Seriousic & $(3.61)$ & & \\
& & $0.0114^{* * *}$ & \\
& & $(2.81)$ & $0.0283^{* * *}$ \\
P-values: Tests of Differences & & & $(3.44)$ \\
Serious > Traffic & & & \\
Controls & & & 0.02 \\
Year Fixed Effects & & & \\
Firm Fixed Effects & & & Yes \\
& Yes & Yes & Yes \\
Adjusted R-squared & Yes & Yes & Yes \\
Observations & Yes & Yes & 0.36 \\
Firms & & & 2,476 \\
Executives & 0.24 & 0.20 & 362 \\
\hline
\end{tabular}


TABLE 3

Panel B: Intra-firm analysis: recordholder classifications and abnormal trading profits from sales

\begin{tabular}{l|ccc}
\hline & \multicolumn{3}{|c}{ Sales } \\
\hline & Record & Traffic & Serious \\
\cline { 2 - 4 } & $(1)$ & $(2)$ & $(3)$ \\
\hline Record & $0.0134^{* * *}$ & & \\
Traffic & $(2.98)$ & & \\
& & $0.0060^{* *}$ & \\
Serious & & $(2.18)$ & $0.0295^{* * *}$ \\
& & & $(3.03)$ \\
$P$-values: Tests of Differences & & & \\
Serious > Traffic & & & 0.01 \\
Controls & & & \\
Year Fixed Effects & & & Yes \\
Firm Fixed Effects & Yes & Yes & Yes \\
& Yes & Yes & Yes \\
Adjusted R-squared & Yes & Yes & \\
Observations & & & 0.39 \\
Firms & 0.17 & 0.15 & 111 \\
Executives & 22,861 & 17,530 & 458 \\
\hline
\end{tabular}

Panel A presents the results of OLS regressions of executive type and trading profits from purchases. Panel B presents the results of OLS regressions of executive type and trading profits from sales. All variables are defined in the Appendix. T-statistics appear in parentheses and are based on standard errors clustered by executive. ***, and **denote statistical significance at the .01 , and .05 levels respectively. 
TABLE 4

Panel A: Abnormal profits from purchases and blackout policies

\begin{tabular}{|c|c|c|c|}
\hline & \multicolumn{3}{|c|}{ Purchases } \\
\hline & Record & Traffic & Serious \\
\hline & $(1)$ & $(2)$ & (3) \\
\hline Record & $\begin{array}{l}0.0191^{* * *} \\
(3.42)\end{array}$ & & \\
\hline Traffic & & $\begin{array}{c}0.0131 * * \\
(2.20)\end{array}$ & \\
\hline Serious & & & $\begin{array}{l}0.0361 * * * \\
\quad(3.01)\end{array}$ \\
\hline Restrict & $\begin{array}{r}0.0030 \\
(0.30)\end{array}$ & $\begin{array}{l}0.0028 \\
(0.25)\end{array}$ & $\begin{array}{c}0.0074 \\
(0.32)\end{array}$ \\
\hline Record * Restrict & $\begin{array}{c}-0.0137 * * \\
(-2.20)\end{array}$ & & \\
\hline Record type * Restrict & & $\begin{array}{c}-0.0270 * * * \\
(-2.61)\end{array}$ & $\begin{array}{l}0.0158 \\
(0.65)\end{array}$ \\
\hline P-values: Summations & & & \\
\hline Restrict + Record type * Restrict & 0.05 & 0.02 & 0.57 \\
\hline & 0.44 & 0.29 & 0.01 \\
\hline P-values: Test of Differences & & & \\
\hline Serious $>$ Traffic & & & 0.02 \\
\hline $\begin{array}{l}\text { Restrict }+ \text { Serious * Restrict }>\text { Restrict }+ \text { Traffic } \\
* \text { Restrict }\end{array}$ & & & 0.01 \\
\hline $\begin{array}{l}\text { Serious + Restrict }+ \text { Serious * Restrict }>\text { Traffic } \\
+ \text { Restrict + Traffic * Restrict }\end{array}$ & & & 0.01 \\
\hline Controls & Yes & Yes & Yes \\
\hline Firm Fixed Effects & Yes & Yes & Yes \\
\hline Year Fixed Effects & Yes & Yes & Yes \\
\hline Adjusted R-squared & 0.25 & 0.23 & 0.36 \\
\hline Observations & 7,406 & 5,230 & 2,476 \\
\hline Firms & 206 & 155 & 89 \\
\hline Executives & 854 & 627 & 362 \\
\hline
\end{tabular}


TABLE 4

Panel B: Abnormal profits from sales and blackout policies

\begin{tabular}{|c|c|c|c|}
\hline & \multicolumn{3}{|c|}{ Sales } \\
\hline & Record & Traffic & Serious \\
\hline & $(1)$ & $(2)$ & $(3)$ \\
\hline Record & $\begin{array}{l}0.0165^{* * *} \\
(2.72)\end{array}$ & & \\
\hline Traffic & & $\begin{array}{l}0.0056 \\
(1.25)\end{array}$ & \\
\hline Serious & & & $\begin{array}{l}0.0285^{* * *} \\
\quad(3.79)\end{array}$ \\
\hline Restrict & $\begin{array}{r}-0.0062 \\
(-0.96)\end{array}$ & $\begin{array}{c}-0.0043 \\
(-0.72)\end{array}$ & $\begin{array}{l}0.0048 \\
(0.35)\end{array}$ \\
\hline Record * Restrict & $\begin{array}{c}-0.0186 * * \\
(-2.10)\end{array}$ & & \\
\hline Record type * Restrict & & $\begin{array}{l}-0.0165 \\
(-1.56)\end{array}$ & $\begin{array}{l}-0.0177 \\
(-1.17)\end{array}$ \\
\hline P-values: Summations & & & \\
\hline $\begin{array}{l}\text { Restrict + Record type * Restrict } \\
\text { Record type + Record type * Restrict }\end{array}$ & 0.02 & 0.08 & 0.30 \\
\hline & 0.87 & 0.45 & 0.10 \\
\hline P-values: Test of Differences & & & \\
\hline Serious $>$ Traffic & & & 0.01 \\
\hline $\begin{array}{l}\text { Restrict }+ \text { Serious * Restrict }>\text { Restrict }+ \\
\text { Traffic * Restrict }\end{array}$ & & & 0.74 \\
\hline $\begin{array}{l}\text { Serious }+ \text { Restrict }+ \text { Serious } * \text { Restrict }> \\
\text { Traffic }+ \text { Restrict }+ \text { Traffic } * \text { Restrict }\end{array}$ & & & 0.01 \\
\hline Controls & Yes & Yes & Yes \\
\hline Firm Fixed Effects & Yes & Yes & Yes \\
\hline Year Fixed Effects & Yes & Yes & Yes \\
\hline Adjusted R-squared & 0.19 & 0.16 & 0.21 \\
\hline Observations & 22,861 & 17,530 & 6,231 \\
\hline Firms & 263 & 202 & 111 \\
\hline Executives & 1,291 & 1,021 & 458 \\
\hline
\end{tabular}

Panel A presents the results of OLS regressions that examine the relation between executives' trading profits from purchases as a function of executive type and blackout policies. Panel B presents the results of OLS regressions that examine the relation between executives' trading profits from sales as a function of executive type and blackout policies. All variables are defined in the Appendix. T-statistics appear in parentheses and are based on standard errors clustered by executive. ${ }^{* * *}$, and ${ }^{* *}$ denote statistical significance at the .01 , and .05 levels respectively. 
TABLE 5

Panel A: Executive type and the propensity to trade during blackout periods

\begin{tabular}{|c|c|c|c|}
\hline & \multicolumn{3}{|c|}{ Sample of Firms with a Blackout Policy } \\
\hline & Record & Traffic & Serious \\
\hline & (1) & (2) & (3) \\
\hline Record & $\begin{array}{c}0.2171^{* *} \\
(2.39)\end{array}$ & & \\
\hline Traffic & & $\begin{array}{c}-0.1406 \\
(-1.29)\end{array}$ & \\
\hline Serious & & & $\begin{array}{c}0.3518^{* * *} \\
(2.43)\end{array}$ \\
\hline P-values: Test of Differences & & & \\
\hline Serious $>$ Traffic & & & 0.01 \\
\hline Controls & Yes & Yes & Yes \\
\hline Firm FE & Yes & Yes & Yes \\
\hline Year FE & Yes & Yes & Yes \\
\hline Pseudo R-squared & 0.02 & 0.02 & 0.02 \\
\hline Observations & 6,493 & 4,440 & 2,019 \\
\hline Firms & 162 & 121 & 55 \\
\hline Executives & 662 & 492 & 231 \\
\hline
\end{tabular}


TABLE 5

Panel B: Executive type and trade size during blackout periods

\begin{tabular}{|c|c|c|c|}
\hline & \multicolumn{3}{|c|}{ Sample of Firms with a Blackout Policy } \\
\hline & Record & Traffic & Serious \\
\hline & $(1)$ & $(2)$ & (3) \\
\hline Record & $\begin{array}{l}-36.24 \\
(-0.69)\end{array}$ & & \\
\hline Traffic & & $\begin{array}{l}-34.84 \\
(-0.77)\end{array}$ & \\
\hline Serious & & & $\begin{array}{l}34.19 \\
(1.42)\end{array}$ \\
\hline Blackout Trade & $\begin{array}{c}-133.51 * \\
(-1.87)\end{array}$ & $\begin{array}{c}-127.75^{*} \\
(-1.90)\end{array}$ & $\begin{array}{c}-43.96 * * * \\
(-2.77)\end{array}$ \\
\hline Record * Blackout Trade & $\begin{array}{l}22.18 \\
(0.29)\end{array}$ & & \\
\hline Record Type * Blackout Trade & & $\begin{array}{l}26.44 \\
(0.33)\end{array}$ & $\begin{array}{l}-21.70 \\
(-0.75)\end{array}$ \\
\hline$P$-values: Summations & & & \\
\hline Blackout Trade + Record Type * Blackout Trade & 0.05 & 0.02 & 0.04 \\
\hline Record type + Record type * Blackout Trade & 0.92 & 0.96 & 0.86 \\
\hline P-values: Test of Differences & & & \\
\hline Serious $>$ Traffic & & & 0.07 \\
\hline Blackout Trade + Serious* Blackout Trade $>$ & & & \\
\hline Blackout Trade +Traffic* Blackout Trade & & & 0.64 \\
\hline Serious + Blackout Trade + Serious* Blackout & & & \\
\hline Trade $>$ Traffic + Blackout Trade +Traffic* & & & \\
\hline Blackout Trade & & & 0.05 \\
\hline Controls & Yes & Yes & Yes \\
\hline Firm Fixed Effects & Yes & Yes & Yes \\
\hline Year Fixed Effects & Yes & Yes & Yes \\
\hline Adjusted R-squared & 0.01 & 0.01 & 0.01 \\
\hline Observations & 6,493 & 4,440 & 2,019 \\
\hline Firms & 162 & 121 & 55 \\
\hline Executives & 662 & 492 & 231 \\
\hline
\end{tabular}

Panel A presents the results of conditional logistic regressions that examine the relation between an executive's type and their propensity to trade in blackout periods. Panel B presents the results of OLS regressions that examine the relation between an executive's type and their trade size in blackout periods. These tests are conducted for the sample of firms with a blackout policy. All variables are defined in the Appendix. Z-Statistics (Panel A) and Tstatistics (Panel B) appear in parentheses and are based on standard errors clustered by executive. ***, **, and * denote statistical significance at the $.01, .05$, and .10 levels respectively. 
TABLE 6

Executive type and Form 4 filings with the SEC

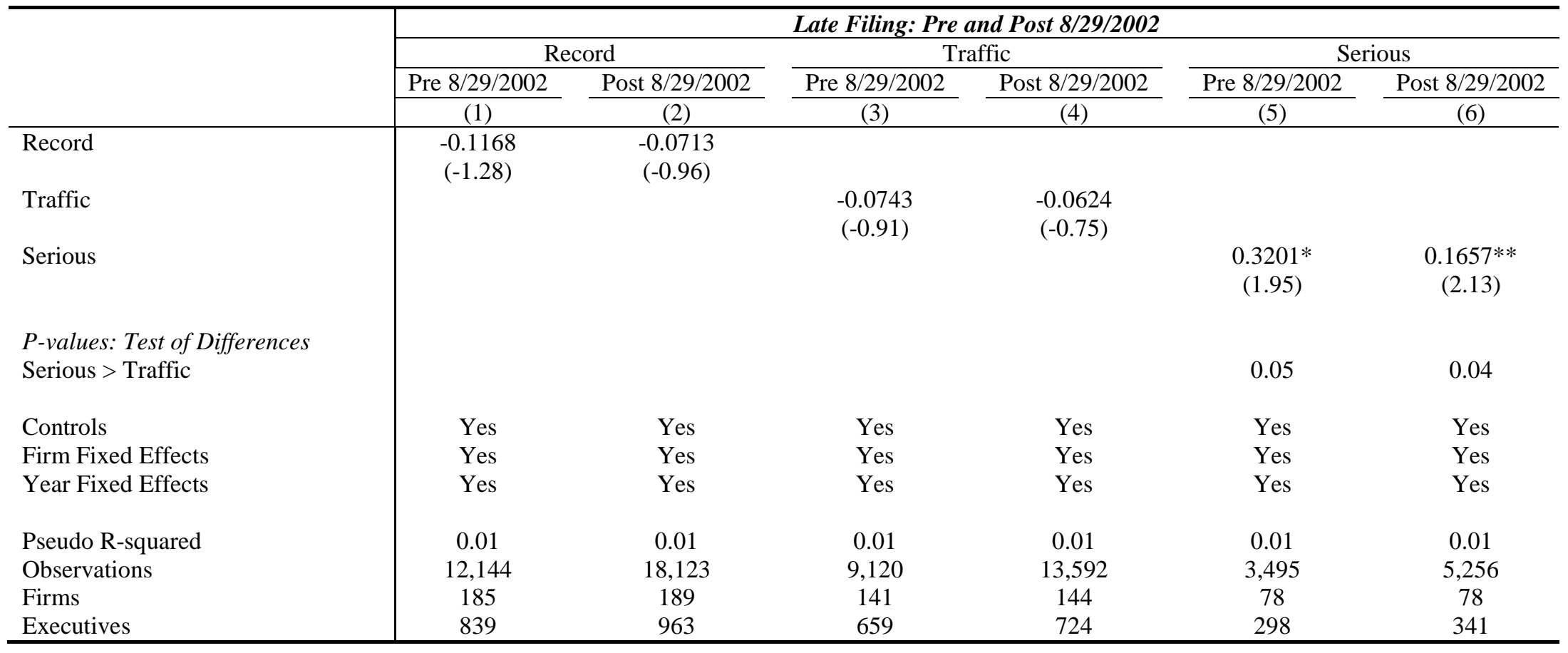

This table presents the results of conditional logistic regressions of executive type and filing Form 4 late with the SEC. Insiders have to file Form 4 no later than the 10th day of the next month following a trade (pre 8/29/2002) or file Form 4 no later than 2 days following the execution of the trade (post 8/29/2002). This table presents the results for both reporting regimes. All variables are defined in the Appendix. Z-statistics appear in parentheses and are based on standard errors clustered by executive. ${ }^{* *}$, and ${ }^{*}$ denote statistical significance at the .05 , and .10 levels respectively. 
TABLE 7

Insider trading before large stock price movements

\begin{tabular}{|c|c|c|c|}
\hline & Record & Traffic & Serious \\
\hline & $(1)$ & $(2)$ & (3) \\
\hline Record & $\begin{array}{l}0.2387^{* * *} \\
(3.39)\end{array}$ & & \\
\hline Traffic & & $\begin{array}{l}0.1931^{* *} \\
(2.10)\end{array}$ & \\
\hline Serious & & & $\begin{array}{l}0.3248^{* * *} \\
\quad(3.41)\end{array}$ \\
\hline $\begin{array}{l}\text { P-values: Test of Differences } \\
\text { Serious > Traffic }\end{array}$ & & & 0.02 \\
\hline Controls & Yes & Yes & Yes \\
\hline Firm Fixed Effects & Yes & Yes & Yes \\
\hline Year Fixed Effects & Yes & Yes & Yes \\
\hline Pseudo R-squared & 0.01 & 0.01 & 0.01 \\
\hline Observations & 26,844 & 20,178 & 7,675 \\
\hline Firms & 237 & 184 & 106 \\
\hline Executives & 1,225 & 971 & 482 \\
\hline
\end{tabular}

This table presents the results of conditional logistic regressions of executive type and propensity to trade before large changes to their firm's stock price. All variables are defined in the appendix. Z-statistics appear in parentheses and are based on standard errors clustered by executive. ${ }^{* * *}$, and ${ }^{* *}$ denote statistical significance at the .01 , and .05 levels respectively. 
TABLE 8

Panel A: Bankruptcy analysis: net share purchases by CEOs before bankruptcy

\begin{tabular}{l|ccc}
\hline & $\begin{array}{c}\text { 36 Months Prior to } \\
\text { Bankruptcy }\end{array}$ & $\begin{array}{c}\text { 72 Months - 36 Months } \\
\text { Prior to Bankruptcy }\end{array}$ & Difference \\
\hline & $-1,622,263$ & 698,866 & $-2,321,129$ \\
Recordholder (N=22) & $-84,882$ & $-329,649$ & 244,767 \\
Nonrecordholder (N=88) & & & \\
& 0.05 & 0.10 & 0.04 \\
\hline -values: Tests of Differences & & & \\
Recordholder > Nonrecordholder & & & \\
\hline
\end{tabular}

TABLE 8

Panel B: Bankruptcy analysis: abnormal profits of CEOs from sales preceding bankruptcy

\begin{tabular}{l|cc}
\hline & \multicolumn{2}{|c}{ Sales Within: } \\
\cline { 2 - 3 } & 36 Months & Before 36 Months \\
& Prior to Bankruptcy & $-0.041^{* * *}$ \\
\hline Intercept & $0.114^{* * *}$ & $(-3.93)$ \\
& $(4.40)$ & 0.024 \\
Record & $0.122^{* * *}$ & $(0.91)$ \\
& $(4.12)$ & \\
Controls & & Yes \\
Adjusted R-squared & Yes & 0.01 \\
Observations & 0.06 & 721 \\
\hline
\end{tabular}

Panel A presents the net share purchases by recordholder and non-recordholder CEOs during the 36 month and 72-36 month periods prior to bankruptcy. A CEO is designated as a Recordholder if he was convicted of any legal infractions; otherwise the CEO is designated as a Nonrecordholder. P-values of the differences are presented as well. Panel B presents the results of OLS regressions of abnormal profits from open market sales by CEOs of firms that declare bankruptcy. All variables are defined in the appendix. T-statistics appear in parentheses and are based on standard errors clustered by executive. ${ }^{* * *}$ denotes statistical significance at the .01 level. 
TABLE 9

Portfolio returns

\begin{tabular}{l|ccc}
\hline & Recordholder & Nonrecordholder & $\begin{array}{c}\text { Recordholder less } \\
\text { Nonrecordholder }\end{array}$ \\
\hline All buys & $1.80^{* * *}$ & $0.92^{* * *}$ & $0.98^{* *}$ \\
All sells & $(3.65)$ & $(3.52)$ & $(2.47)$ \\
& $-0.48^{* *}$ & -0.13 & $-0.35^{*}$ \\
Buys - sells & $(-1.99)$ & $(-0.43)$ & $(-1.70)$ \\
& $2.21^{* * *}$ & $1.05^{* * *}$ & $1.16^{* *}$ \\
& $(3.40)$ & $(2.94)$ & $(2.34)$ \\
\hline
\end{tabular}

This table shows the returns to equal weighted buy and sell portfolios for recordholder and nonrecordholder executives that follow all trades using Trading Profits as computed from a four factor alpha model, where $\alpha$ is obtained from estimating transaction-day specific regressions of daily returns over the 180-days following each transaction. An executive is designated as a recordholder if he was convicted of any legal infractions; otherwise the executive is designated as a nonrecordholder. A firm is included in the buy portfolio, for example, in month $m+1$ if any insider for which we have legal infractions data places a buy on the firm in month $\mathrm{m}$. T-statistics are presented in parentheses. ${ }^{* * *}$, and ${ }^{* *}$ denote statistical significance at the .01 , and .05 levels respectively. 


\section{Appendix: Definition of main variables and data sources}

\begin{tabular}{|c|c|c|}
\hline Variable & Definition & Data Source \\
\hline Record & $\begin{array}{l}\text { An indicator variable that equals } 1 \text { if an executive has any legal } \\
\text { infractions, and } 0 \text { otherwise. Legal infractions include driving under } \\
\text { the influence of alcohol, other drug-related charges, assault, domestic } \\
\text { violence, reckless behavior, sexual assault and traffic violations } \\
\text { (including speeding tickets). }\end{array}$ & $\begin{array}{l}\text { Find Out the } \\
\text { Truth.com (FOTT). }\end{array}$ \\
\hline Traffic & $\begin{array}{l}\text { An indicator variable that equals } 1 \text { if an executive has only traffic } \\
\text { infractions, and } 0 \text { otherwise. }\end{array}$ & $\begin{array}{l}\text { Find Out the } \\
\text { Truth.com (FOTT). }\end{array}$ \\
\hline Serious & $\begin{array}{l}\text { An indicator variable that equals } 1 \text { if an executive has any serious legal } \\
\text { infractions, and } 0 \text { otherwise. Serious legal infractions include driving } \\
\text { under the influence of alcohol, other drug-related charges, assault, } \\
\text { domestic violence, reckless behavior, and sexual assault. }\end{array}$ & $\begin{array}{l}\text { Find Out the } \\
\text { Truth.com (FOTT). }\end{array}$ \\
\hline Multiple & $\begin{array}{l}\text { An indicator variable that equals } 1 \text { if an executive has more than one } \\
\text { infraction, and } 0 \text { otherwise. }\end{array}$ & $\begin{array}{l}\text { Find Out the } \\
\text { Truth.com (FOTT). }\end{array}$ \\
\hline Trading Profits & $\begin{array}{l}\text { Equals } \alpha(-\alpha) \text { for purchases (sales) made by insiders (who file SEC } \\
\text { Form } 16) \text {, where } \alpha \text { is obtained from estimating transaction-day specific } \\
\text { regressions of daily returns on common factors over the } 180 \text {-days } \\
\text { following each transaction: }(\mathrm{Rj}-\mathrm{Rf})=\alpha+\beta 1 \text { (Rmkt }-\mathrm{Rf})+\beta 2 \mathrm{SMB} \\
+\beta 3 \mathrm{HML}+\beta 4 \mathrm{UMD}+\mathrm{e} \text {. Rj is the daily return to firm j's equity, Rf is } \\
\text { the daily risk-free interest rate, Rmkt is the CRSP value-weighted } \\
\text { market return, and SMB, HML, and UMD are the size, book-to- } \\
\text { market, and momentum factors. }\end{array}$ & $\begin{array}{l}\text { Thomson Reuters, } \\
\text { CRSP and Fama- } \\
\text { French data. }\end{array}$ \\
\hline Trade Size & The number of shares traded in thousands. & Thomson Reuters. \\
\hline Trade Frequency & The average number of trades an executive makes per year. & Thomson Reuters. \\
\hline Blackout Trade & $\begin{array}{l}\text { An indicator variable that equals } 1 \text { if the trade was executed during a } \\
\text { blackout period, and } 0 \text { otherwise. The blackout period is the period } \\
\text { outside the } 21 \text { trading days following a quarterly earnings } \\
\text { announcement. }\end{array}$ & $\begin{array}{l}\text { Thomson Reuters } \\
\text { and Compustat. }\end{array}$ \\
\hline Late Filing & $\begin{array}{l}\text { An indicator variable that equals } 1 \text { if the insider filed Form } 4 \text { late, and } \\
0 \text { otherwise. }\end{array}$ & Thomson Reuters. \\
\hline CAR Trade & $\begin{array}{l}\text { An indicator variable that equals } 1 \text { for purchases (sales) executed } \\
\text { within the } 60 \text { days prior to a positive (negative) } 3 \text {-day cumulative } \\
\text { abnormal return at least } 3 \text { standard deviations from the firm’s mean } \\
\text { CAR, and } 0 \text { otherwise. }\end{array}$ & $\begin{array}{l}\text { Thomson Reuters } \\
\text { and CRSP. }\end{array}$ \\
\hline Total & The sum of cash salary, cash bonus, other annual cash compensation, & ExecuComp. \\
\hline Compensation & $\begin{array}{l}\text { long-term incentive payouts, and the value of stock options and shares } \\
\text { of restricted stock granted to the executive during the year (in } \\
\text { millions). }\end{array}$ & \\
\hline Wealth & $\begin{array}{l}\text { The natural logarithm of the sum of firm-based wealth (measured as in } \\
\text { Coles et al. 2013) and non-firm-based wealth (measured as in Dittmann } \\
\text { and Maug 2007). }\end{array}$ & $\begin{array}{l}\text { ExecuComp and the } \\
\text { website of Ingolf } \\
\text { Dittman. }\end{array}$ \\
\hline Size & $\begin{array}{l}\text { The natural logarithm of a firm's market capitalization at fiscal year- } \\
\text { end. }\end{array}$ & Compustat. \\
\hline Market-to-book & $\begin{array}{l}\text { The ratio of the market and book values of a firm's equity at fiscal } \\
\text { year-end. }\end{array}$ & Compustat. \\
\hline Return & The firm's annual stock return. & CRSP. \\
\hline Restrict & $\begin{array}{l}\text { An indicator variable that equals } 1 \text { if } 75 \% \text { or more of the firm's trading } \\
\text { volume occurs outside of the blackout period, and } 0 \text { otherwise. The } \\
\text { blackout period is the period outside the } 21 \text { trading days following a } \\
\text { quarterly earnings announcement. }\end{array}$ & $\begin{array}{l}\text { Thomson Reuters } \\
\text { and Compustat. }\end{array}$ \\
\hline
\end{tabular}

